CIRC 854-B

\title{
Seismic Engineering Program Report May-August 1980
}

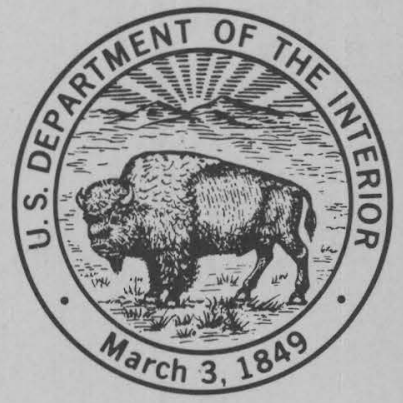

Prepared on behalf of the National Science Foundation Grant CA-114

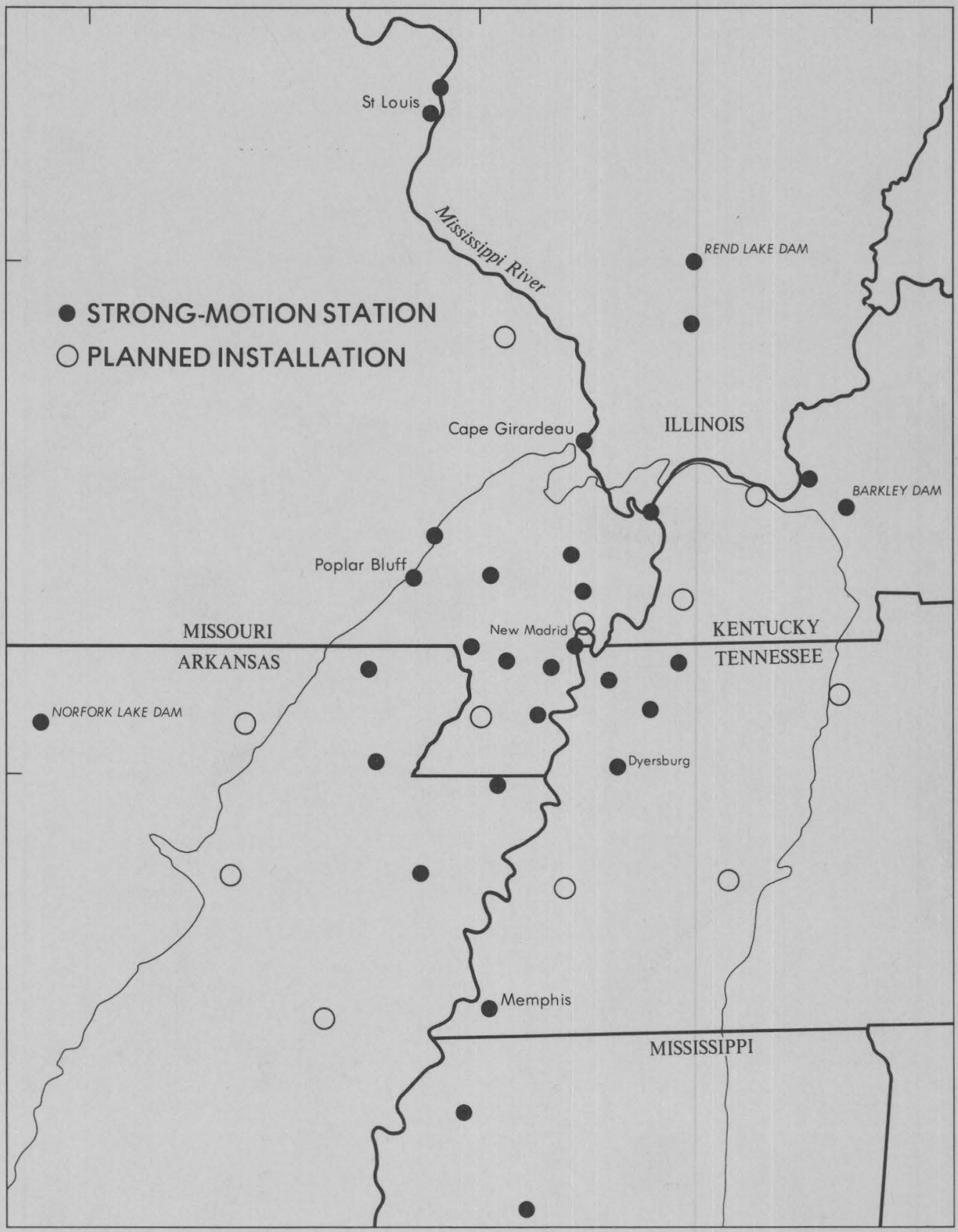

GEOLOGICAL SURVEY CIRCULAR 854-B 

Seismic Engineering

Program Report,

May-August 1980

GEOLOGICAL SURVEY CIRCULAR 854-B

Prepared on behalf of the

National Science Foundation

Grant CA-114 


\section{United States Department of the Interior}

JAMES G. WATT, Secretary

\section{Geological Survey}

Dallas L. Peck, Director

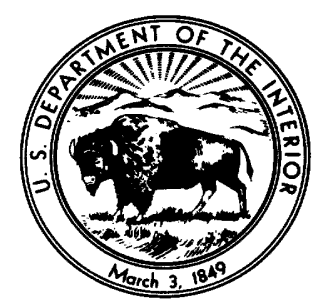




\section{PREFACE}

This Seismic Engineering Program Report is an informal periodical primarily intended to keep the ever-growing international community of strong-motion data users apprised of the nature and availability of daca recovered by the Seismic Engineering Branch of the U.S. Geological Survey (UJGS). This StrongMotion Program is administered by the USGS and supporte by the National Science Foundation (Grant CA-114) in cooperation with numerous Federal, State, and local agencies and organizations. Major objectives of the program include recording both strong ground motion and the response of various types of engineered structures during potentially damaging earthquaikes and disseminating this strong-motion information and data to the earthquake engineering research and design community.

This issue contains a summary of the accelerograms recuvered from the USGS National Strong-Motion Network during the period May i through August 31, 1980. A report on the New Madrid Strong-Motion Network, a revision of strongmotion data recorded during the February 25, 1980, Horse Canyon (Anza) earthquake, and some comments about atypical acceleroyrams recorded during recent earthquakes are included along with summaries of recent strong-motion reports, notes on the availability of digitized data, and additional general information pertinent to the USGS and to other strong-riotion programs. The data summary included in table 1 contains information un those accelerograms recovered (although not necessarily recorded) during the period May-August 1980; this procedure has been adopted so that the dissemination of strong-motion information may be as expeditious and current as practicable.

Ronald L. Porcella, Editor

U.S. Geological Survey, Mail Stop 78

Menlo Park, California 94025 


\section{CONTENTS}

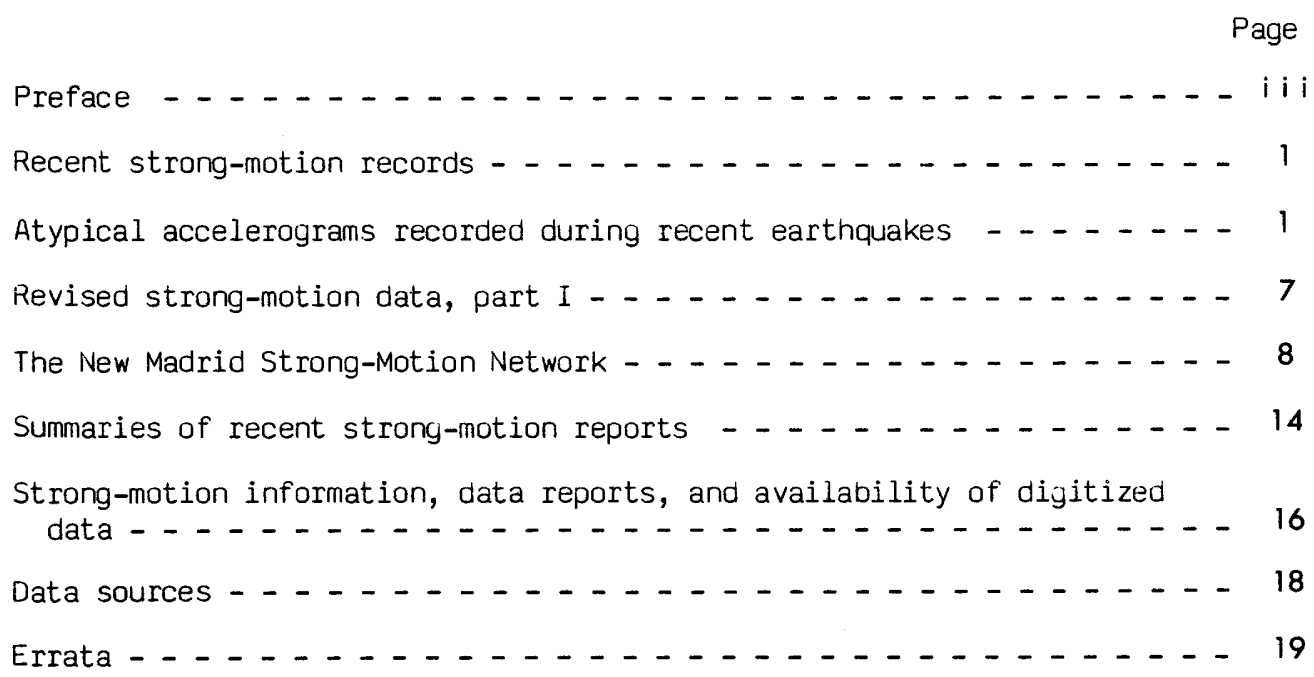

\section{TABLES}

Table 1 - Summary of accelerograms, May - August $1980 \ldots$ - . - . - . 20

2 - Strong-motion data from the Horse Canyuri earthquake - . . . . 4

3 - Accelerograph stations in the New Madiıd Network _. . . . . 10

4 - New Madrid strong-motion data _ . . . . . . . . . . . . . 13

\section{ILLUSTRATIONS}

Figure 1 - Comparison of accelerograms from Bonds Lorner, Cerro Prieto, and Long Valley Dam _..................... 2

2 - Location map for the New Madrid Strong-motion Network - - - - 9 



\section{SEISMIC ENGINEERING PROGRAM REPORT, MAY - AUGUST 1980}

\section{RECENT STRONG-MOTION RECORDS}

\author{
By R. L. Porcella and J. C. Switzer
}

The Mammoth Lakes, California, earthquake sequence of May 1980 produced 153 strong-motion records from 34 USGS accelerographs located at six dams, two pumping plants, and one V.A. hospital in the San Joaquin valley region. Most of these records are thought to be related to four magnitude $6+$ earthquakes; their times of occurrence (UTC) and local (Berkeley) magnitudes are May 25, 16:33, 6.1; May 25, 16:49, 6.0; May 25, 19:44, 6.1; and May 27, 14:50, 6.2. Because of the large epicentral distances for the USGS stations, only four of the 153 records contain peak accelerations greater than $0.05 \mathrm{~g}$ (see table 1, end of report). The California Division of Mines and Geology, office of Strong-motion Studies (OSMS) recorded more than one thousand data traces on accelerographs located at 14 OSMS stations in the Mammoth Lakes region during the period May 25 through May 28; approximately 350 of these traces show peak accelerations greater than $0.05 \mathrm{~g}$ (Turpen, 1980) .

Thirty additional records were recovered from the USGS National Network during the period May 1 to August 31, 1980. The magnitude 6.1 northern Mexico earthquake of June 9 triggered nine USGS accelerographs at Imperial Valley, California, strong-motion stations; a peak acceleration of $0.13 \mathrm{~g}$ and strong duration (acceleration greater than $0.1 \mathrm{~g}$ ) of 1.6 seconds was recorded at the Bonds Corner station. All other USGS recordings show ground accelerations less than $0.05 \mathrm{~g}$. Additional records were recovered in northern Mexico at seven stations jointly operated by the National University of Mexico and the University of California, San Diego. Maximum ground accelerations greater than $0.1 \mathrm{~g}$ were recorded at three stations within $35 \mathrm{~km}$ of the epicenter; a digital accelerograph at Victoria (epicentral distance $7 \mathrm{~km}$ ) recorded a maximum horizontal acceleration greater than $0.8 \mathrm{~g}$ and a maximum vertical acceleration greater than $1.0 \mathrm{~g}$, though parts of the recording could not be recovered (Anderson and others, 1982). An analog recorder at Cerro Prieto (epicentral distance $31 \mathrm{~km}$ ) produced a maximum acceleration greater than $0.5 \mathrm{~g}$ and strong shaking (greater than $0.1 \mathrm{~g}$ ) for about seven seconds (see the following report).
Other accelerograms recovered during this reporting period include records related to earthquakes near Maysville, Kentucky, and Bear Valley and Livermore, California (see table I).

References:

Anderson, J. G., Prince, J., Brune, J. N., and Simons, R. S., 1982, Strong-motion accelerograms, in Anderson, J. G., and Simons, R. S., eds., The Mexicali Valley earthquake of 9 June 1980: Earthquake Engineering Research Institute Newsletter, v. 16, no. 3, p. 79-83.

Turpen, C. D., 1980, Strong-motion records from the Mammoth Lakes earthquakes of May 1980: California Division of Mines and Geology Preliminary Report 27, $42 \mathrm{p}$.

\section{ATYPICAL ACCELEROGRAMS RECORDED DURING RECENT EARTHQQUAKES}

\author{
By R. L. Porcella
}

The June 9, 1980, magnitude 6.1 northern Mexico earthquake triggered seven strong-motion stations in Baja California (see "Recent Strong-Motion Records," this report). One of the accelerograms, recorded at the Cerro Prieto station, is particularly interesting because it contains several large-amplitude, highfrequency spikes that are remarkably similar to acceleration traces recorded at the Bonus Corner station during the October 15, 1979, Imperial valley earthquake (Porcella and Matthiesen, 1979) and at the Long Valley Dam left abutment station during the May 1980 Mammoth Lakes earthquakes (Turpen, 1980; see figure 1). These three strong-motion stations are notably dissimilar in terms of geologic setting, epicentral distance, instrument housing, and local site conditions.

Bonds Corner is located approximately $15 \mathrm{~km}$ east of Calexico, Calif., and is situated on more than $6,000 \mathrm{~m}$ of Cenozoic deposits derived from the Colorado River and nearby mountain ranges. The strong-motion station is located in a one-story, agricultural equipment repair building situated on a concrete slab about $20 \times 15 \mathrm{~m}$; the building is steel (I-beam) frame with corrugated iron sides and roof. The near-surface material at the site consists of at least $30 \mathrm{~m}$ of very dense sand, with $0.5-$ to 2-m-thick layers of clayey silt at the surface and at depths of 9 and $12 \mathrm{~m}$ (R. Porcella, unpub. data, 1982). 
BONDS CORNER - 10/15/79, 2316 UTC:ML=6.6

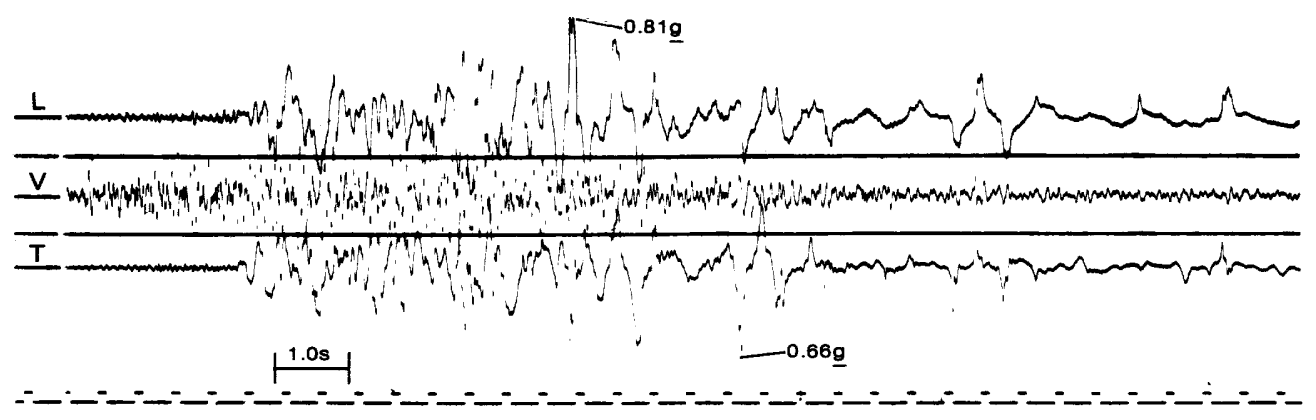

CERRO PRIETO $-6 / 09 / 80,0328$ UTC: $\mathrm{M}_{\mathrm{L}}=6.1$

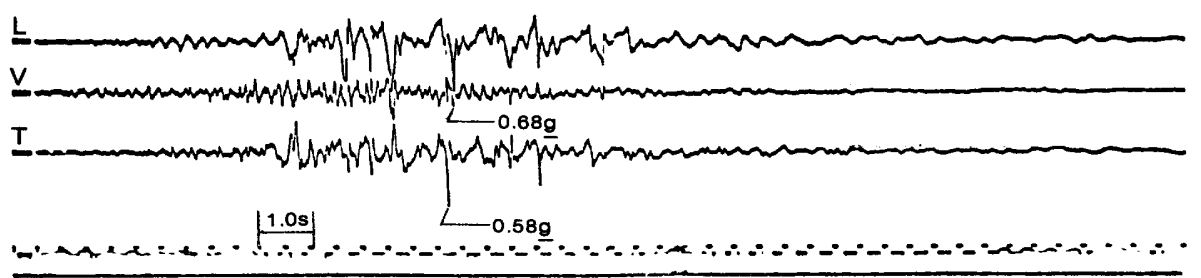

LONG VALLEY DAM $-5 / 25 / 80,1633$ UTC: $M_{L}=6.1$
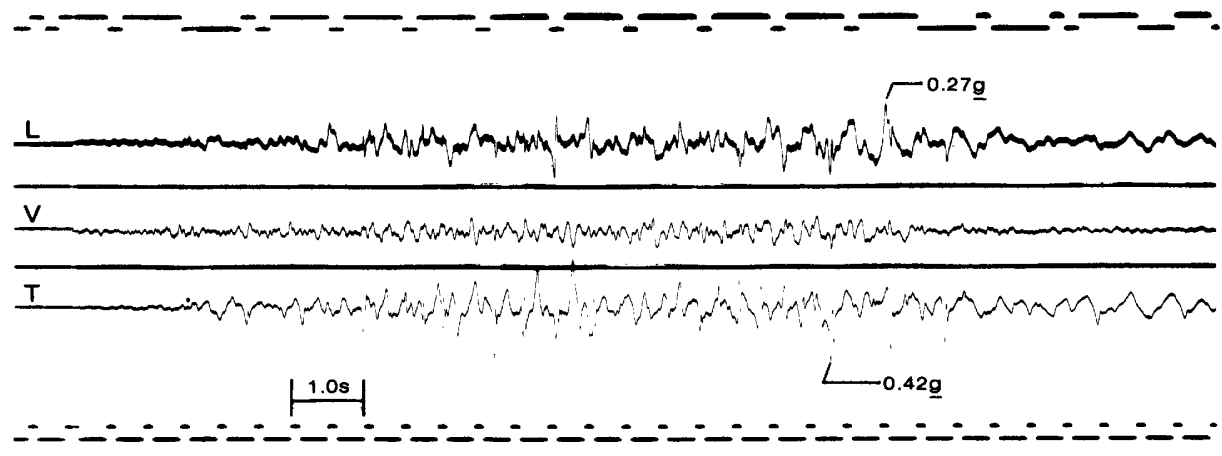

Figure 1.- Atypical accelerograms from Bonds Corner and Long Valley Dam, California and Cerro Prieto, Baja California. 
LONG VALLEY DAM -5/25/80, 1649 UTC: $M_{L}=6.0$

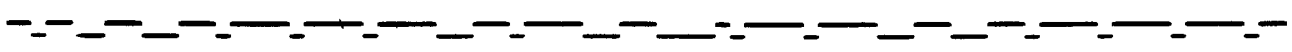

L

V

T

$$
<0.19 \underline{g}
$$

- - - - - -

LONG VALLEY DAM -5/25/80, 1944 UTC:ML=6.1

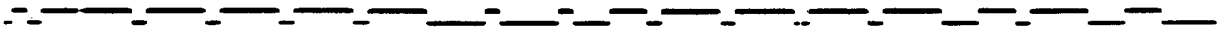

L

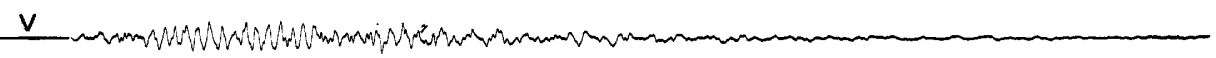

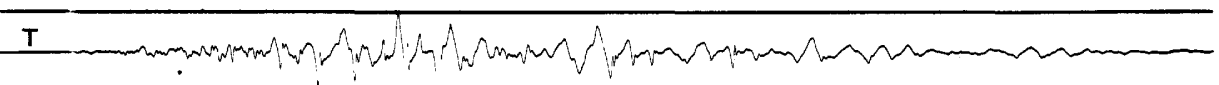

-

LONG VALLEY DAM $-5 / 27 / 80,1450$ UTC: $M_{L}=6.2$

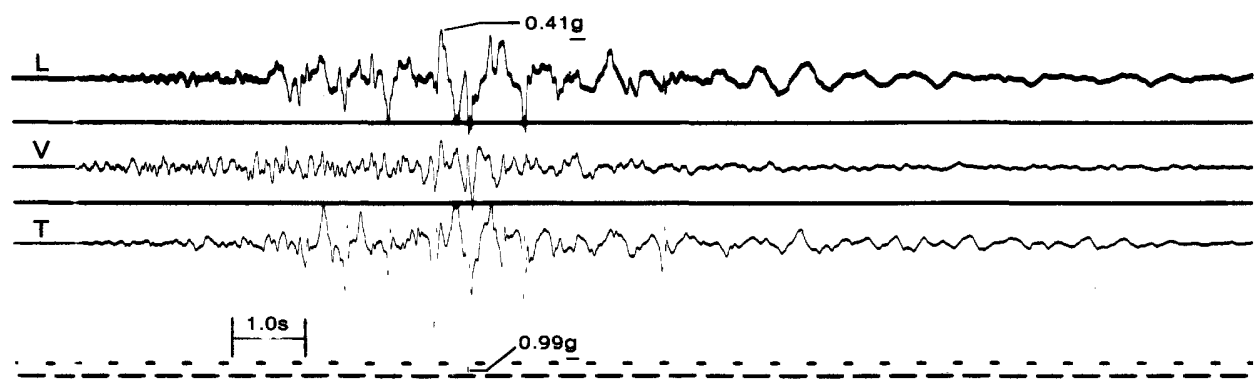

Figure 1.- continued. 
Table 2.- Strong-motion data from the Horse Canyon (Anza) earthquake of February 25, 1980

\begin{tabular}{|c|c|c|c|c|c|c|}
\hline \multicolumn{4}{|c|}{ Strong-motion station } & \multicolumn{3}{|c|}{ Ground acceleration } \\
\hline $\begin{array}{l}\text { Name, } \\
\text { Owner, } \\
\text { I.D. number }\end{array}$ & Coordinat & & $\begin{array}{l}\text { Epicentral } \\
\text { distance } 1 \\
(\mathrm{~km})\end{array}$ & Az imuth ${ }^{2}$ & $\begin{array}{l}\text { Peak } \\
(g)\end{array}$ & $\begin{array}{c}\text { Duration } 3 \\
(\mathrm{~s})\end{array}$ \\
\hline $\begin{array}{l}\text { Anza Fire Station } \\
\text { USGS } \\
5160\end{array}$ & $\begin{array}{r}33.556 \\
116.673\end{array}$ & & 12.1 & $\begin{array}{l}315 \\
\text { Up } \\
225\end{array}$ & $\begin{array}{r}0.073 \\
.041 \\
.067\end{array}$ & $\begin{array}{l}- \\
-\end{array}$ \\
\hline $\begin{array}{l}\text { Borrego Air Ranch } \\
\text { USGS } \\
5049\end{array}$ & $\begin{array}{r}33.19 \\
116.28\end{array}$ & $\begin{array}{l}N \\
W\end{array}$ & 41.4 & $\begin{array}{l}315 \\
\text { Up } \\
225\end{array}$ & $\begin{array}{l}.032 \\
.016 \\
.040\end{array}$ & $\begin{array}{l}- \\
-\end{array}$ \\
\hline $\begin{array}{l}\text { Cabazon Post Office } \\
\text { USGS } \\
5073\end{array}$ & $\begin{array}{r}33.92 \\
116.78\end{array}$ & $\begin{array}{l}N \\
W\end{array}$ & 49.2 & $\begin{array}{l}270 \\
\text { Up } \\
180\end{array}$ & $\begin{array}{l}.017 \\
.011 \\
.016\end{array}$ & $\begin{array}{l}- \\
-\end{array}$ \\
\hline $\begin{array}{l}\text { Cherry Valley } \\
\text { USGS } \\
5074\end{array}$ & $\begin{array}{r}33.98 \\
116.99\end{array}$ & $\begin{array}{l}N \\
W\end{array}$ & 65.3 & $\begin{array}{l}295 \\
\text { Up } \\
205\end{array}$ & $\begin{array}{l}.011 \\
.011 \\
.011\end{array}$ & $\begin{array}{l}- \\
-\end{array}$ \\
\hline $\begin{array}{l}\text { Coachella Canal Sta. } 1 \\
\text { USGS } \\
2063\end{array}$ & $\begin{array}{r}33.64 \\
116.08\end{array}$ & $\begin{array}{l}N \\
W\end{array}$ & 42.4 & $\begin{array}{l}135 \\
\text { Up } \\
045\end{array}$ & $\begin{array}{l}- \\
.021 \\
.030\end{array}$ & $\begin{array}{l}- \\
-\end{array}$ \\
\hline $\begin{array}{l}\text { Cranston Forest Sta. } \\
\text { USGS } \\
5042\end{array}$ & $\begin{array}{r}33.74 \\
116.84\end{array}$ & $\begin{array}{l}N \\
W\end{array}$ & 36.3 & $\begin{array}{l}135 \\
\text { Up } \\
045\end{array}$ & $\begin{array}{l}.110 \\
.038 \\
.094\end{array}$ & $\begin{array}{l}\text { l-peak } \\
- \\
-\end{array}$ \\
\hline $\begin{array}{l}\text { Fun Valley } \\
\text { USGS } \\
5069\end{array}$ & $\begin{array}{r}33.93 \\
116.40\end{array}$ & $\begin{array}{l}N \\
W\end{array}$ & 47.7 & $\begin{array}{l}270 \\
\text { Up } \\
180\end{array}$ & $\begin{array}{l}.028 \\
.011 \\
.033\end{array}$ & $\begin{array}{l}- \\
-\end{array}$ \\
\hline $\begin{array}{l}\text { Hemet City Library } \\
\text { CDMG } \\
\text { C266 (5091) }\end{array}$ & $\begin{array}{r}33.748 \\
116.965\end{array}$ & $\begin{array}{l}N \\
W\end{array}$ & 46.1 & $\begin{array}{l}270 \\
\text { Up } \\
360\end{array}$ & $\begin{array}{l}.057 \\
.058 \\
.046\end{array}$ & $\begin{array}{l}- \\
-\end{array}$ \\
\hline $\begin{array}{l}\text { Hurkey Creek Park } \\
\text { USGS } \\
5043\end{array}$ & $\begin{array}{r}33.67 \\
116.68\end{array}$ & $\begin{array}{l}N \\
W\end{array}$ & 20.6 & $\begin{array}{l}135 \\
\text { Up } \\
045\end{array}$ & $\begin{array}{l}.075 \\
.101 \\
.097\end{array}$ & 1-peak \\
\hline $\begin{array}{l}\text { Indio } \\
\text { USGS } \\
5067\end{array}$ & $\begin{array}{r}33.75 \\
116.21\end{array}$ & $\begin{array}{l}N \\
W\end{array}$ & 38.5 & $\begin{array}{l}315 \\
\text { Up } \\
225\end{array}$ & $\begin{array}{l}.094 \\
.020 \\
.060\end{array}$ & $\begin{array}{l}- \\
-\end{array}$ \\
\hline
\end{tabular}

See footnotes at end of table 
Table 2.- Strong-motion data from the Horse Canyon (Anza) earthquake of February 25, 1980 - cont inued

\begin{tabular}{|c|c|c|c|c|c|c|}
\hline \multicolumn{4}{|c|}{ Strong-motion station } & \multicolumn{3}{|c|}{ Ground acceleration } \\
\hline $\begin{array}{l}\text { Name, } \\
\text { Owner, } \\
\text { I.D. number }\end{array}$ & Coordinat & tes & $\begin{array}{l}\text { Epicentral } \\
\text { distance } 1 \\
(\mathrm{~km})\end{array}$ & Azimuth ${ }^{2}$ & $\begin{array}{l}\text { Peak } \\
(\mathrm{g})\end{array}$ & $\begin{array}{l}\text { Duration } \\
\text { (s) }\end{array}$ \\
\hline $\begin{array}{l}\text { Mathews (Dike: Toe) } \\
\text { USGS } \\
707\end{array}$ & $\begin{array}{r}33.852 \\
117.451\end{array}$ & & 91.3 & $\begin{array}{l}245 \\
\text { Up } \\
155\end{array}$ & $\begin{array}{r}0.015 \\
.011 \\
.011\end{array}$ & $\begin{array}{l}- \\
-\end{array}$ \\
\hline $\begin{array}{l}\text { Morongo Valley } \\
\text { USGS } \\
5071\end{array}$ & $\begin{array}{r}34.05 \\
116.58\end{array}$ & $\begin{array}{l}N \\
W\end{array}$ & 58.8 & $\begin{array}{l}135 \\
\text { Up } \\
045\end{array}$ & $\begin{array}{l}.016 \\
.016 \\
.016\end{array}$ & $\begin{array}{l}- \\
-\end{array}$ \\
\hline $\begin{array}{l}\text { N. Palm Springs } \\
\text { USGS } \\
5070\end{array}$ & $\begin{array}{r}33.92 \\
116.54\end{array}$ & $\begin{array}{l}\text { N } \\
\text { W }\end{array}$ & 44.4 & $\begin{array}{l}300 \\
\text { Up } \\
210\end{array}$ & $\begin{array}{l}.022 \\
.028 \\
.017\end{array}$ & $\begin{array}{l}- \\
-\end{array}$ \\
\hline $\begin{array}{l}\text { Palm Desert } \\
\text { CDMG } \\
\text { C284 (5132) }\end{array}$ & $\begin{array}{r}33.762 \\
116.407\end{array}$ & $\begin{array}{l}N \\
W\end{array}$ & 29.5 & $\begin{array}{l}360 \\
\text { Up } \\
090\end{array}$ & $\begin{array}{l}.094 \\
.054 \\
.072\end{array}$ & $\begin{array}{l}- \\
-\end{array}$ \\
\hline $\begin{array}{l}\text { Pinyon Flat 0bserv. } \\
\text { USGS } \\
5044\end{array}$ & $\begin{array}{r}33.61 \\
116.46\end{array}$ & $\begin{array}{l}N \\
W\end{array}$ & 12.0 & $\begin{array}{l}135 \\
\text { Up } \\
045\end{array}$ & $\begin{array}{l}.133 \\
.058 \\
.118\end{array}$ & $\begin{array}{c}0.5 \\
- \\
\text { 1-peak }\end{array}$ \\
\hline $\begin{array}{l}\text { Puerta La Cruz } \\
\text { CDMG } \\
\text { C168 (933) }\end{array}$ & $\begin{array}{r}33.32 \\
116.68\end{array}$ & $\begin{array}{l}\mathrm{N} \\
\mathrm{W}\end{array}$ & 25.3 & $\begin{array}{l}350 \\
\text { Up } \\
260\end{array}$ & $\begin{array}{l}.114 \\
.090 \\
.181\end{array}$ & $\begin{array}{l}0.3 \\
- \\
0.3\end{array}$ \\
\hline $\begin{array}{l}\text { Rancho De Anza } \\
\text { USGS } \\
5047\end{array}$ & $\begin{array}{r}33.35 \\
116.40\end{array}$ & $\begin{array}{l}N \\
W\end{array}$ & 20.5 & $\begin{array}{l}135 \\
\text { Up } \\
045\end{array}$ & $\begin{array}{l}.096 \\
.051 \\
.096\end{array}$ & $\begin{array}{l}- \\
-\end{array}$ \\
\hline $\begin{array}{l}\text { Sage } \\
\text { CDMG } \\
\text { C118 (901) }\end{array}$ & $\begin{array}{r}33.580 \\
116.932\end{array}$ & $\begin{array}{l}N \\
W\end{array}$ & 36.1 & $\begin{array}{l}335 \\
\text { Up } \\
245\end{array}$ & $\begin{array}{l}.084 \\
.174 \\
.111\end{array}$ & $\begin{array}{c}- \\
0.2 \\
1-\text { peak }\end{array}$ \\
\hline $\begin{array}{l}\text { San Bernardino Hilton } \\
\text { CDMG } \\
\text { C287 (5134) }\end{array}$ & $\begin{array}{r}34.065 \\
117.279\end{array}$ & $\begin{array}{l}N \\
W\end{array}$ & 90.1 & $\begin{array}{l}070 \\
\text { Up } \\
160\end{array}$ & $\begin{array}{l}.016 \\
.008 \\
.027\end{array}$ & $\begin{array}{l}- \\
-\end{array}$ \\
\hline $\begin{array}{l}\text { San Jacinto } \\
\text { CDMG } \\
\text { C203 (5005) }\end{array}$ & $\begin{array}{r}33.784 \\
116.948\end{array}$ & $\begin{array}{l}N \\
W\end{array}$ & 47.1 & $\begin{array}{l}360 \\
\text { Up } \\
270\end{array}$ & $\begin{array}{l}.062 \\
.052 \\
.080\end{array}$ & $\begin{array}{l}- \\
-\end{array}$ \\
\hline $\begin{array}{l}\text { San Jacinto } \\
\text { CDMG } \\
\text { C204 (5006) }\end{array}$ & $\begin{array}{r}33.80 \\
116.88\end{array}$ & $\begin{array}{l}N \\
W\end{array}$ & 43.6 & $\begin{array}{l}025 \\
\text { Up } \\
295\end{array}$ & $\begin{array}{l}.047 \\
.064 \\
.044\end{array}$ & - \\
\hline
\end{tabular}

See footnotes at end of table 
Table 2.- Strong-motion data from the Horse Canyon (Anza) earthquake of February 25, 1980 - continued

\begin{tabular}{|c|c|c|c|c|c|c|}
\hline \multicolumn{4}{|c|}{ strong-motion station } & \multicolumn{3}{|c|}{ Ground acceleration } \\
\hline $\begin{array}{l}\text { Name, } \\
\text { Owner, } \\
\text { I.D. number }\end{array}$ & Coordina & tes & $\begin{array}{l}\text { Epicentral } \\
\text { distancel } \\
(\mathrm{km})\end{array}$ & Azimuth ${ }^{2}$ & $\begin{array}{l}\text { Peak } \\
(\mathrm{g})\end{array}$ & $\begin{array}{c}\text { Duration } \\
\text { (s) }\end{array}$ \\
\hline $\begin{array}{l}\text { Terwilliger Valley } \\
\text { USGS } \\
5045\end{array}$ & $\begin{array}{r}33.48 \\
116.59\end{array}$ & $\begin{array}{l}N \\
W\end{array}$ & 5.8 & $\begin{array}{l}135 \\
\text { Up } \\
045\end{array}$ & $\begin{array}{r}0.088 \\
.063 \\
.123\end{array}$ & $\overline{-}$ \\
\hline $\begin{array}{l}\text { Thousand Palms P.0. } \\
\text { USGS } \\
5068\end{array}$ & $\begin{array}{r}33.82 \\
116.40\end{array}$ & $\begin{array}{l}N \\
W\end{array}$ & 35.9 & $\begin{array}{l}135 \\
\text { Up } \\
045\end{array}$ & $\begin{array}{l}.050 \\
.049 \\
.082\end{array}$ & $\begin{array}{l}- \\
-\end{array}$ \\
\hline $\begin{array}{l}\text { Whitewater Trout Farm } \\
\text { USGS } \\
5072\end{array}$ & $\begin{array}{r}33.99 \\
116.66\end{array}$ & $\begin{array}{l}N \\
W\end{array}$ & 53.1 & $\begin{array}{l}270 \\
\text { Up } \\
180\end{array}$ & $\begin{array}{l}.016 \\
.022 \\
.022\end{array}$ & $\begin{array}{l}- \\
-\end{array}$ \\
\hline
\end{tabular}

1 Distance from epicenter at $33.51 \mathrm{~N}$. 1at., $116.53 \mathrm{w}$. long. When coordinates of station and/or source are listed to 0.01 degree, the implication is an accuracy in epicentral distance of approximately $1 \mathrm{~km}$; a program of upgrading all station coordinates to 0.001 degrees is under way.

2 Azimuthal direction (degrees clockwise from north) of case acceleration for upward trace deflection on accelerogram; vertical component listed as Up or Down.

3 Time between first and last peaks of acceleration greater than $0.10 \mathrm{~g}$. 
The Long Valley Dam strong-motion station is located in Owens Valley, Calif., at Lake Crowley; the dam abutments are founded on Pleistocene volcanic rock (Bishop Tuff). The left abutment instrument is housed in a prefabricated corrugated iron shelter mounted on a concrete pad about $2 \times 2 \times 0.3 \mathrm{~m}$ thick; less than $0.5 \mathrm{~m}$ of soil is present between the base of the pad and bedrock (R. McJunkin, oral commun., 1982).

The Cerro Prieto strong-motion station is located near the rim of Cerro Prieto volcano in Baja California, Mexico; the instrument is mounted in a $0.5 \times 0.7 \times 0.3-m-h i g h$ metal enclosure. The accelerograph is attached to a $0.8 \times 1.2 \mathrm{~m}$ concrete pad situated on a blocky basaltic material at an elevation of $170 \mathrm{~m}$ ( $\mathrm{J}$. Anderson, oral commun, 1982).

In addition to earthquake magnitudes, one notable similarity is that the events triggered three stations that contain SMA-l triaxial accelerographs equipped with flexure-type $1 \mathrm{~g}$ accelerometers, which have a natural frequency of $25 \mathrm{~Hz}, 60$ percent critical damping, bandwidth of $0.1-25 \mathrm{~Hz}$, and a sensitivity or maximum $1 \mathrm{~g}$ deflection of about $18 \mathrm{~mm}$ on $70-\mathrm{mm}$ photographic film. To reconfirm the validity of the apparently unusual high-frequency response during the strong ground motion, plans have been fmade to install RFT-250 accelerographs (with torsion-type accelerometers) alongside and interconnected with the SMA-1 instruments at Bonds Corner and Long Valley Dam left abutment. It is hoped that future recordings from these stations will contain some indication of the origin and nature of these high-frequency, large amplitude spikes. These peak accelerations may not be representative and may have biased acceleration data for stations at similar distances in ground-motion attenuation studies.

The records from Bonds Corner and Cerro Prieto have been digitized and are available from the Environmental Data and Information Service; the Long Valley Dam processed data is available from COMG (see "Data Sources," this report).

\section{References:}

Anderson, J. G., Prince, J., Brune, J. N., and Simons, R. S., 1982, Strong-motion accelerograms, in Anderson, J. G., and Simons, R. S., eds., The Mexicali Valley earthquake of 9 June 1980: Earthquake Engineering Research Institute Newsletter, $v .16$, no. 3 , p. 79-83.

Porcella, R. L., and Matthiesen, R. B., 1979, Preliminary report on the U.S. Geological Survey strong-motion records from the October 15, 1979, Imperial Valley earthquake: U.S. Geological Survey Open-File Report 79-1654, 41 p.

Turpen, C. D., 1980, Strong-motion records from the Mammoth Lakes earthquakes of May 1980: California Division of Mines and Geology Preliminary Report 27, $42 \mathrm{p}$.

\section{REVISED STRONG-MOTION DATA, PART I}

\author{
By R. L. Porcella
}

One of the primary purposes of this program report is to disseminate periodically strongmotion information and data from the U.S. Geological Survey's National Network to the international earthquake engineering community. USGS strong-motion data is currently published triannually and includes the azimuth, duration, and amplitude of peak accelerations greater than 5 percent $g$; these amplitudes are scaled from the original records and are listed to the nearest one-hundredth of a g (see table 1 , for example). This peak-motion data has been used often in recent years in studies of the attenuation characteristics of horizontal ground acceleration for varying earthquake magnitudes, source-site distances, source mechanisms, and recording-site conditions (see for example, Trifunac and Brady, 1976; Hanks and Johnson, 1976; Boore and others 1978, 1980; Boore and Porcella, 1980; Campbell, 1981; Hanks and McGuire, 1981; and Joyner and Boore, 1981).

Because of the recent and dramatic increase in strong-motion data at both far- and nearsource distances, it has become apparent that more detailed lists of the recorded ground accelerations and also source-site distances for selected earthquakes would be useful to various seismological studies including groundmotion attenuation. Data from the Horse Canyon (Anza) : earthquake of February 25, 1980 (Porcella, 1982), has been re-scaled to one-thousandth of $a \mathrm{~g}$ and together with recordings from the California Division of Mines and Geology's office of Strong-Motion Studies is presented in table 2; also listed are epicentral distances. Additional strong-motion data that have been or will be re-scaled are related to California earthquakes near El Centro and Coyote Lake (Gilroy) in 1979, and Livermore in 1980; the amended results will be published in future issues of this program report.

References:

Boore, D. M., Joyner, W. B., Oliver, A. A., III, and Page, R. A., 1978, Estimation of ground motion parameters: U.S. Geological Survey Circular 795, 43 p.

1980, Peak acceleration, velocity, and displacement from strong-motion records: Bulletin Seismological Society America, v. 70, p. 305-321.

Boore, D. M., and Porcella, R. L., 1980, Peak acceleration from strong-motion records: $s$ postscript: Bulletin of the Seismological Society of America, v. 70, p. 2295-2297.

Campbell, K. W., 1981, Near-source attenuation of peak horizontal acceleration: Bulletin of the Seismological Society of America, $v$. 71 , p. 2039-2070.

Hanks, T. C., and Johnson, D. A., 1976, Geophysical assessment of peak accelerations: 
Bulletin of the Seismological Society of America, v. 66, p. 959-968.

Hanks, T. C. and MCGuire, R. K., 1981, The character of high-frequency strong ground motion: Bulletin of the Seismological Society of America, v. 71, p. 2071-2095.

Joyner, W. B. and Boore, D. M., 1981, Peak horizontal acceleration and velocity from strong-motion records including records from the 1979 Imperial Valley, California, earthquake: Bulletin of the Seismological Society of America, v. 71 , p. 2011-2038.

Porcella, R. L., ed., 1982, Seismic Engineering Program Report, January - April 1980, 21 p.

Trifunac, M. D., and Brady, A. G., 1976, Correlations of peak acceleration, velocity, and displacement with earthquake magnitude, distance, and site conditions: Earthquake Engineering and Structural Dynamics, v. 4, p. 455-471.

\section{THE NEW MADRID STRONG-MOTION NETWORK}

\section{By R. L. Porcella}

The U.S. strong-motion instrumentation program in the central United States began in July 1969 when the U.S. Coast and Geodetic Survey established a strong-motion station at Southeast Missouri College in Cape Girardeau, Missouri. During the following 6 years, 13 additional stations were established primarily as a result of joint USGS programs with the U.S. Army Corps of Engineers (COE) and the Veterans Administration (VA); the programs were developed largely in response to the 1971 San Fernando, Calif., earthquake that severely damaged the Olive View and VA hospital facilities and caused near failure of the lower San Fernando Dam.

Dams in the New Madrid seismic zone that have been instrumented under the USGS-COE program include those at Arkabutla and Sardis Lakes, Mississippi; Wappapello Lake, Missouri; Barkley Lake, Kentucky; and Smithland Locks and Rend Lake, Illinois (fig. 2; table 3). The typical COE strong-motion installation in this zone includes an earthfill embankment and appurtenant structures instrumented with from three to six triaxial accelerographs at various locations including the crest, toe, downstream, abutment, spillway, and outlet tower.

$V A$ hospitals in the New Madrid network that were instrumented under the USGS-VA program include those at Memphis, Tennessee; Marion, Illinois; and Poplar Bluff and St." Louis, Missouri (fig. 2; table 3). In 1973, a triaxial accelerograph generally was installed in the basement of the major building at each of these facilities for the purpose of measuring the base motions of large hospital buildings during potentially damaging earthquakes (Porcella, 1978). Additionally, strong-motion stations were established at the Noranda aluminum plant near New Madrid, Missouri, in
1972 and at Reelfoot Lake near Tiptonville, Tennessee, in 1975.

Based on recent microearthquake activity, historical seismicity, and the lower attenuation of ground motion associated with earthquakes in the central United States, a study by Matthiesen (1978) suggested that a uniform rate of strong-motion recording might be expected for the Mississippi embayment region - - comparable to rates associated with the Transverse Ranges or segments of the Hayward or Calaveras faults in California. During the latter part of 1977 and in 1978 the USGS established 14 of 25 additional strong-motion stations designated for inclusion in a 40-station, variable-grid network incorporating two roughly perpendicular arrays in the northern part of the Mississippi River embayment. One array will extend along the axis of the embayment from Forrest City, Arkansas, to Cairo, Illinois, at $15-50 \mathrm{~km}$ spacings; the second array will extend from the lower Paleozoic sedimentary rock at Poplar Bluff, Missouri, across the Quaternary alluvial deposits and Eocene sedimentary rock of the embayment to the Cretaceous sedimentary rock at Paris, Tennessee (fig. 2; willden and Carlson, 1968). The placement of these stations was primarily based on recently recorded microseismic activity (see, for example, Stauder and others, 1980) and the geology of the embayment region. The primary purposes of establishing the New Madrid network are: (1) to obtain strong-motion data for use in quantitative studies of the differences in the attenuation of ground motion in this region as compared with California and the western United States and (2) to determine the spectral characteristics of strong ground motion in the embayment region, and the variation of these characteristics as they relate to the source mechanism, travel path geometries, regional geologic setting, and local site conditions (Porcella, 1978). Detailed geophysical studies at strongmotion sites that include measurement of $\mathrm{P}$ - and $S$-wave velocities are anticipated as part of the various aftershock activities that will be undertaken when a significant set of groundmotion data is recorded in the New Madrid seismic zone.

Three earthquakes have been recorded at stations in the New Madrid network; a magnitude 4.5 event on June 13, 1975, a magnitude 5.0 event on March 24, 1976, and a magnitude 4.5 aftershock of the March 24 earthquake (see table 4). The June 13, 1975, earthquake triggered the accelerograph at the New Madrid station and produced a maximum recorded acceleration of $0.076 \mathrm{~g}$ at an epicentral distance of about $10 \mathrm{~km}$. The March 24, 1976, earthquake near Marked Tree, Arkansas, triggered seven accelerographs at four stations located at epicentral distances of 104 to $144 \mathrm{~km}$; the March 24 aftershock triggered one station at an epicentral distance of $107 \mathrm{~km}$ (table 4). These nine accelerograms represent the entire strong- 


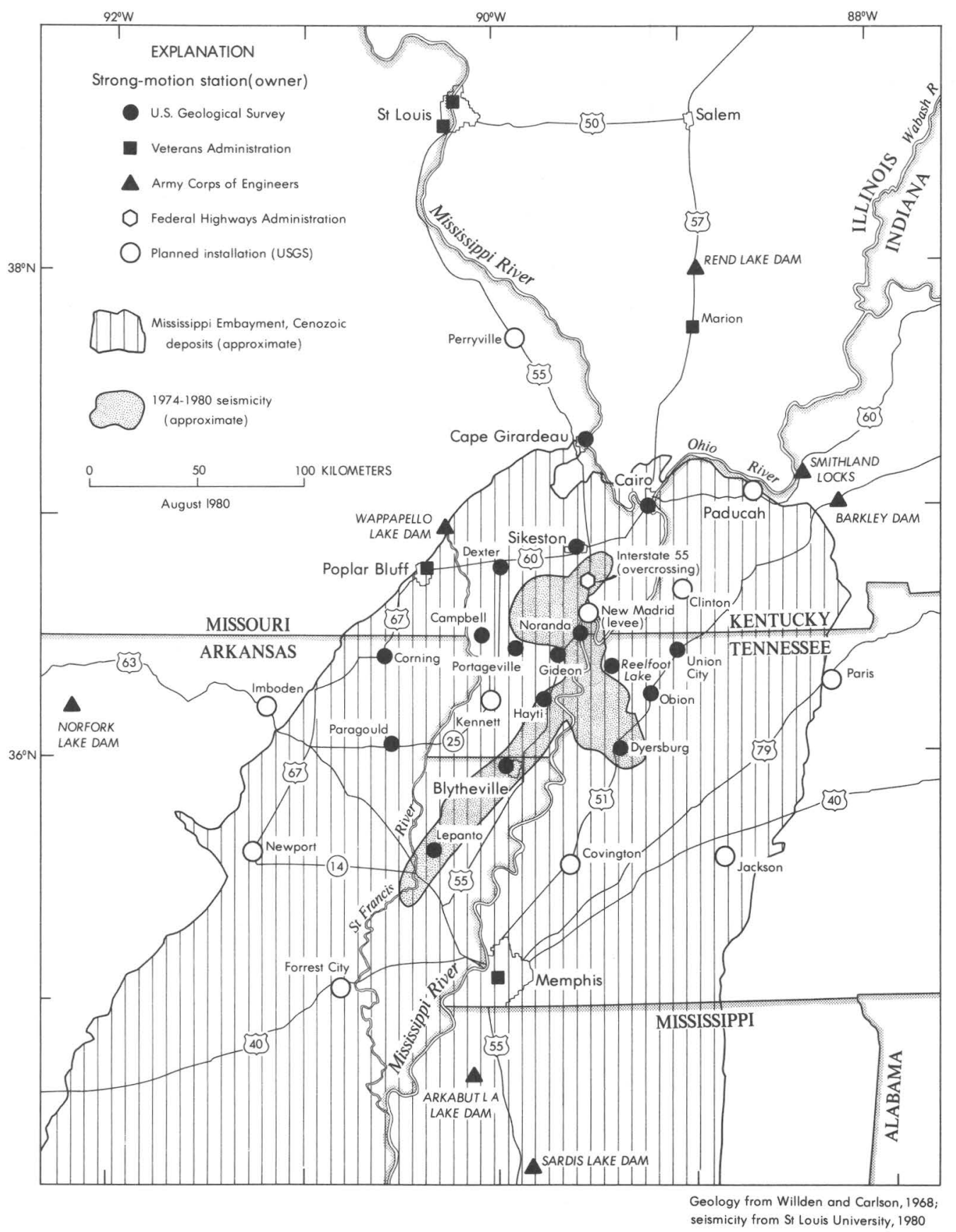

Figure 2. - New Madrid Strong-Motion Network. 
Table 3.- Accelerograph stations in the New Madrid Strong-Motion Network

\begin{tabular}{|c|c|c|c|c|c|c|}
\hline $\begin{array}{l}\text { Station, } \\
\text { Owner, I.D. no. }\end{array}$ & Coordin & ates & $\begin{array}{l}\text { Structure } \\
\text { type, Size }\end{array}$ & $\begin{array}{l}\text { Instrument } \\
\text { location }(s)\end{array}$ & $\begin{array}{l}\text { Date } \\
\text { installed }\end{array}$ & $\begin{array}{l}\text { Local } \\
\text { geology }\end{array}$ \\
\hline $\begin{array}{l}\text { Arkabutla Dam, Miss. } \\
\text { ACOE, } 2444\end{array}$ & $\begin{array}{l}34.76 \\
90.12\end{array}$ & $\begin{array}{l}N \\
W\end{array}$ & $\begin{array}{l}\text { earth dam, } \\
3940 \times 21 \mathrm{~m} h i \\
\text { embankment }\end{array}$ & $\begin{array}{l}\text { abutment, } \\
\text { toe, crest }\end{array}$ & $5-21-73$ & $\begin{array}{l}\text { Tertiary } \\
\text { sed. rock }\end{array}$ \\
\hline $\begin{array}{l}\text { Bark ley Dam, Ky. } \\
\text { ACOE, } 2427\end{array}$ & $\begin{array}{l}37.02 \\
88.22\end{array}$ & $\begin{array}{l}N \\
W\end{array}$ & earth dam & $\begin{array}{l}\text { crest, abut., } \\
\text { downstream, } \\
\text { spillway(2) }\end{array}$ & $1-14-75$ & $\begin{array}{l}\text { Cretaceous } \\
\text { sed. rock }\end{array}$ \\
\hline $\begin{array}{l}\text { Blytheville, Ark. } \\
\text { Fire Station } \# 2 \\
\text { USGS, } 2449\end{array}$ & $\begin{array}{l}35.928 \\
89.926\end{array}$ & $\begin{array}{l}N \\
W\end{array}$ & $\begin{array}{l}\text { wood/brick, } \\
\text { steel frame, } \\
\text { l-story bldg. }\end{array}$ & $\begin{array}{l}\text { ground } \\
\text { level }\end{array}$ & $10-22-77$ & $\begin{array}{l}\text { Quaternary } \\
\text { alluv. } \\
\text { deposits }\end{array}$ \\
\hline $\begin{array}{l}\text { Cairo, I11.: } \\
\text { Fire Station } \\
\text { USGS, } 2451\end{array}$ & $\begin{array}{l}37.003 \\
87.173\end{array}$ & $\begin{array}{l}N \\
W\end{array}$ & $\begin{array}{l}\text { concrete block, } \\
\text { steel frame, } \\
\text { l-story bldg. }\end{array}$ & $\begin{array}{l}\text { ground } \\
\text { level }\end{array}$ & $10-17-77$ & $\begin{array}{l}\text { Quaternary } \\
\text { alluv. } \\
\text { deposits }\end{array}$ \\
\hline $\begin{array}{l}\text { Campbel1, Mo. } \\
\text { Fire Station } \\
\text { USGS, } 2454\end{array}$ & $\begin{array}{l}36.494 \\
90.075\end{array}$ & $\begin{array}{l}N \\
W\end{array}$ & $\begin{array}{l}\text { concrete block, } \\
\text { steel frame, } \\
\text { l-story bldg. }\end{array}$ & $\begin{array}{l}\text { ground } \\
\text { level }\end{array}$ & $10-18-77$ & $\begin{array}{l}\text { Tertiary } \\
\text { sed. rock }\end{array}$ \\
\hline $\begin{array}{l}\text { Cape Girardeau, Mo. } \\
\text { SE Mo. State College } \\
\text { USGS, } 2403\end{array}$ & $\begin{array}{l}37.316 \\
89.529\end{array}$ & $\begin{array}{l}N \\
W\end{array}$ & $\begin{array}{l}\text { reinforced } \\
\text { concrete, } \\
2 \text {-story bldg. }\end{array}$ & basement & $7-3-69$ & $\begin{array}{l}\text { Ordovician } \\
\text { sed. rock }\end{array}$ \\
\hline $\begin{array}{l}\text { Corning, Ark. } \\
\text { Post office } \\
\text { USGS, } 2455\end{array}$ & $\begin{array}{l}36.41 \\
90.58\end{array}$ & $\begin{array}{l}N \\
W\end{array}$ & $\begin{array}{l}\text { concrete block, } \\
\text { l-story bldg. }\end{array}$ & $\begin{array}{l}\text { ground } \\
\text { level }\end{array}$ & $10-19-77$ & $\begin{array}{l}\text { Quaternary } \\
\text { alluv. } \\
\text { deposits }\end{array}$ \\
\hline $\begin{array}{l}\text { Dexter, Mo. } \\
\text { Fire Station \#2 } \\
\text { USGS, } 2457\end{array}$ & $\begin{array}{l}36.796 \\
89.966\end{array}$ & $\begin{array}{l}N \\
W\end{array}$ & $\begin{array}{l}\text { pre-stressed } \\
\text { concrete, } \\
\text { l-story bidg. }\end{array}$ & $\begin{array}{l}\text { ground } \\
\text { level }\end{array}$ & $7-16-78$ & $\begin{array}{l}\text { Tertiary } \\
\text { sed. rock }\end{array}$ \\
\hline $\begin{array}{l}\text { Oyersburg, Tenn. } \\
\text { Fire Station \#2 } \\
\text { USGS, } 2461\end{array}$ & $\begin{array}{l}36.05 \\
89.39\end{array}$ & $\begin{array}{l}N \\
W\end{array}$ & $\begin{array}{l}\text { concrete block, } \\
\text { steel frame, } \\
\text { l-story bldg. }\end{array}$ & $\begin{array}{l}\text { ground } \\
\text { level }\end{array}$ & $7-17-78$ & $\begin{array}{l}\text { Tertiary } \\
\text { sed. rock }\end{array}$ \\
\hline $\begin{array}{l}\text { Gideon, Mo. } \\
\text { City Hall } \\
\text { USGS, } 2456\end{array}$ & $\begin{array}{l}36.454 \\
89.919\end{array}$ & $\begin{array}{l}N \\
W\end{array}$ & $\begin{array}{l}\text { concrete block, } \\
\text { brick veneer, } \\
\text { l-story bldg. }\end{array}$ & $\begin{array}{l}\text { ground } \\
\text { level }\end{array}$ & $10-20-77$ & $\begin{array}{l}\text { Quaternary } \\
\text { alluv. } \\
\text { deposits }\end{array}$ \\
\hline $\begin{array}{l}\text { Hayt i, Mo. } \\
\text { Medical Center } \\
\text { USGS, } 2448\end{array}$ & $\begin{array}{l}36.237 \\
89.740\end{array}$ & $\begin{array}{l}N \\
W\end{array}$ & $\begin{array}{l}\text { reinf. conc., } \\
\text { brick veneer, } \\
\text { 3-story bldg. }\end{array}$ & $\begin{array}{l}\text { ground } \\
\text { level }\end{array}$ & $10-22-77$ & $\begin{array}{l}\text { Quaternary } \\
\text { alluv. } \\
\text { deposits }\end{array}$ \\
\hline $\begin{array}{l}\text { Interstate } 55 \\
\text { Rte P Bridge } \\
\text { FHWY, } 2477\end{array}$ & $\begin{array}{l}36.66 \\
89.67\end{array}$ & $\begin{array}{l}N \\
W\end{array}$ & $\begin{array}{l}\text { reinf. conc., } \\
\text { conc. piles, } \\
64 \mathrm{~m}-1 \text { long brdge }\end{array}$ & $\begin{array}{l}13 \text { channel, } \\
\text { remote } \\
\text { recording }\end{array}$ & $10-20-80$ & $\begin{array}{l}\text { Quaternary } \\
\text { alluv. } \\
\text { deposits }\end{array}$ \\
\hline
\end{tabular}


Table 3.- Accelerograph stations in the New Madrid Strong-Motion Network - continued

\begin{tabular}{|c|c|c|c|c|c|c|}
\hline $\begin{array}{l}\text { Station, } \\
\text { Owner, I.D. no. }\end{array}$ & Coordina & ates & $\begin{array}{l}\text { Structure } \\
\text { type, Size }\end{array}$ & $\begin{array}{l}\text { Instrument } \\
\text { location }(\mathrm{s})\end{array}$ & $\begin{array}{l}\text { Date } \\
\text { installed }\end{array}$ & $\begin{array}{l}\text { Local } \\
\text { geology }\end{array}$ \\
\hline $\begin{array}{l}\text { Lepanto, Ark. } \\
\text { Fire Station } \\
\text { USGS, } 2458\end{array}$ & $\begin{array}{l}35.613 \\
90.330\end{array}$ & $\begin{array}{l}N \\
W\end{array}$ & $\begin{array}{l}\text { concrete block, } \\
\text { steel frm roof, } \\
\text { l-story bldg. }\end{array}$ & $\begin{array}{l}\text { ground } \\
\text { level }\end{array}$ & $7-12-78$ & $\begin{array}{l}\text { Quaternary } \\
\text { alluv. } \\
\text { deposits }\end{array}$ \\
\hline $\begin{array}{l}\text { Marion, Ill. } \\
\text { V.A. Hospital } \\
\text { VA, } 2411\end{array}$ & $\begin{array}{l}37.72 \\
88.95\end{array}$ & $\begin{array}{l}N \\
W\end{array}$ & $\begin{array}{l}\text { 8-stall garage, } \\
\text { 1-story bldg. }\end{array}$ & $\begin{array}{l}\text { ground } \\
\text { level }\end{array}$ & $5-14-73$ & $\begin{array}{l}\text { Pennsylvanian } \\
\text { rock }\end{array}$ \\
\hline $\begin{array}{l}\text { Memphis, Tenn. } \\
\text { V.A. Hospital } \\
\text { VA, } 2410\end{array}$ & $\begin{array}{l}35.14 \\
90.03\end{array}$ & $\begin{array}{l}N \\
W\end{array}$ & 13-story bldg. & basement & $5-12-73$ & $\begin{array}{l}\text { Quaternary } \\
\text { alluv. } \\
\text { deposits }\end{array}$ \\
\hline $\begin{array}{l}\text { New Madrid, Mo. } \\
\text { Noranda Plant } \\
\text { USGS, } 2420\end{array}$ & $\begin{array}{l}36.51 \\
89.57\end{array}$ & $\begin{array}{l}N \\
W\end{array}$ & $\begin{array}{l}\text { concrete block, } \\
\text { l-story bldg. }\end{array}$ & $\begin{array}{l}\text { ground } \\
\text { level }\end{array}$ & $2-29-72$ & $\begin{array}{l}\text { Quaternary } \\
\text { alluv. } \\
\text { deposits }\end{array}$ \\
\hline $\begin{array}{l}\text { Norfork Dam, Ark. } \\
\text { ACOE, } 2401\end{array}$ & $\begin{array}{l}36.25 \\
92.23\end{array}$ & $\begin{array}{l}N \\
W\end{array}$ & $\begin{array}{l}\text { concrete dam, } \\
800 \times 66 \mathrm{~m} \mathrm{hi} \text {. }\end{array}$ & $\begin{array}{l}\text { crest, } \\
\text { lower gallery }\end{array}$ & $12-8-71$ & $\begin{array}{l}\text { Ordovician } \\
\text { sed. rock }\end{array}$ \\
\hline $\begin{array}{l}\text { Obion, Tenn. } \\
\text { Police Dept. } \\
\text { USGS, } 2460\end{array}$ & $\begin{array}{l}36.259 \\
89.192\end{array}$ & $\begin{array}{l}N \\
W\end{array}$ & $\begin{array}{l}\text { concrete block, } \\
\text { steel/t in roof, } \\
1 \text {-story bldg. }\end{array}$ & $\begin{array}{l}\text { ground } \\
\text { leve } 1\end{array}$ & $7-15-78$ & $\begin{array}{l}\text { Quaternary } \\
\text { alluv. } \\
\text { deposits }\end{array}$ \\
\hline $\begin{array}{l}\text { Paragould, Ark. } \\
\text { Post Office } \\
\text { USGS, } 2459\end{array}$ & $\begin{array}{l}36.06 \\
90.49\end{array}$ & $\begin{array}{l}N \\
W\end{array}$ & $\begin{array}{l}\text { concrete block, } \\
\text { l-story bldg. }\end{array}$ & basement & $7-13-78$ & $\begin{array}{l}\text { Tertiary } \\
\text { sed. rock }\end{array}$ \\
\hline $\begin{array}{l}\text { Poplar Bluff, Mo. } \\
\text { V.A. Hospital } \\
\text { VA, } 2409\end{array}$ & $\begin{array}{l}36.77 \\
90.42\end{array}$ & $\begin{array}{l}N \\
W\end{array}$ & $\begin{array}{l}\text { reinf. conc., } \\
6 \text {-story bidg. }\end{array}$ & basement & $5-11-73$ & $\begin{array}{l}\text { Ordovician } \\
\text { sed. rock }\end{array}$ \\
\hline $\begin{array}{l}\text { Portageville, Mo. } \\
\text { Post Office } \\
\text { USGS, } 2452\end{array}$ & $\begin{array}{l}36.428 \\
89.704\end{array}$ & $\begin{array}{l}N \\
W\end{array}$ & $\begin{array}{l}\text { conc. block, } \\
\text { stee } 1 / \text { t in roof, } \\
\text { l-story bldg. }\end{array}$ & $\begin{array}{l}\text { ground } \\
\text { level }\end{array}$ & $10-18-77$ & $\begin{array}{l}\text { Quaternary } \\
\text { alluv. } \\
\text { deposits }\end{array}$ \\
\hline $\begin{array}{l}\text { Rend Dam, I11. } \\
\text { ACOE, } 2422\end{array}$ & $\begin{array}{l}38.02 \\
88.99\end{array}$ & $\begin{array}{l}N \\
W\end{array}$ & $\begin{array}{l}\text { earth dam, } \\
3230 \times 16 \mathrm{~m} \mathrm{hi} \\
\text { embankment }\end{array}$ & $\begin{array}{l}\text { crest, } \\
\text { toe, } \\
\text { spiliway }\end{array}$ & $4-27-74$ & $\begin{array}{l}\text { Pennsylvanian } \\
\text { rock }\end{array}$ \\
\hline $\begin{array}{l}\text { St. Louis, Mo. } \\
\text { Cochran Hospital } \\
\text { VA, } 2408\end{array}$ & $\begin{array}{l}38.64 \\
90.23\end{array}$ & $\begin{array}{l}N \\
W\end{array}$ & 10-story bldg. & basement & $5-10-73$ & $\begin{array}{l}\text { Mississippian } \\
\text { sed. rock }\end{array}$ \\
\hline $\begin{array}{l}\text { St. Louis, Mo. } \\
\text { Jeff. Barracks Hosp. } \\
\text { VA, } 2407\end{array}$ & $\begin{array}{l}38.49 \\
90.28\end{array}$ & $\begin{array}{l}N \\
W\end{array}$ & l-story bldg. & $\begin{array}{l}\text { ground } \\
\text { level }\end{array}$ & $5-9-73$ & $\begin{array}{l}\text { Mississippian } \\
\text { sed. rock }\end{array}$ \\
\hline
\end{tabular}


Table 3.- Accelerograph stations in the New Madrid Strong-Motion Network - continued

\begin{tabular}{|c|c|c|c|c|c|c|}
\hline $\begin{array}{l}\text { Station, } \\
\text { Owner, I.D. no. }\end{array}$ & Coordina & ates & $\begin{array}{l}\text { Structure } \\
\text { type, Size }\end{array}$ & $\begin{array}{l}\text { Instrument } \\
\text { location }(s)\end{array}$ & $\begin{array}{c}\text { Date } \\
\text { installed }\end{array}$ & $\begin{array}{l}\text { Local } \\
\text { geology }\end{array}$ \\
\hline $\begin{array}{l}\text { Sardis Dam, Miss. } \\
\text { ACOE, } 2445\end{array}$ & $\begin{array}{l}34.41 \\
89.80\end{array}$ & $\begin{array}{l}N \\
W\end{array}$ & $\begin{array}{l}\text { earth dam, } \\
4667 \times 30 \mathrm{~m} \mathrm{hi}\end{array}$ & $\begin{array}{l}\text { abutment, } \\
\text { toe, crest }\end{array}$ & $5-22-73$ & $\begin{array}{l}\text { Tertiary } \\
\text { sed. rock }\end{array}$ \\
\hline $\begin{array}{l}\text { Sikeston, Mo. } \\
\text { Fire Station } \\
\text { USGS, } 2453\end{array}$ & $\begin{array}{l}36.883 \\
89.580\end{array}$ & $\begin{array}{l}N \\
W\end{array}$ & $\begin{array}{l}\text { conc. block, } \\
\text { stl/wood roof, } \\
\text { l-story bldg. }\end{array}$ & $\begin{array}{l}\text { ground } \\
\text { level }\end{array}$ & $10-16-77$ & $\begin{array}{l}\text { Quaternary } \\
\text { alluv. } \\
\text { deposits }\end{array}$ \\
\hline $\begin{array}{l}\text { Smithland Dam, I11. } \\
\text { ACOE, } 2462\end{array}$ & $\begin{array}{l}37.164 \\
88.433\end{array}$ & $\begin{array}{l}N \\
W\end{array}$ & $\begin{array}{l}\text { earth dam, } \\
\text { gated section, } \\
\text { (2) locks }\end{array}$ & $\begin{array}{l}\text { freefield(2), } \\
\text { upper gallery } \\
\text { of locks }\end{array}$ & $5-1-78$ & $\begin{array}{l}\text { Mississippian } \\
\text { sed. rock }\end{array}$ \\
\hline $\begin{array}{l}\text { Tiptonville, Tenn. } \\
\text { Reelfoot Lake } \\
\text { USGS, } 2446\end{array}$ & $\begin{array}{l}36.37 \\
89.41\end{array}$ & $\begin{array}{l}N \\
W\end{array}$ & $\begin{array}{l}\text { wood frame, } \\
\text { l-story bldg. }\end{array}$ & $\begin{array}{l}\text { ground } \\
\text { level }\end{array}$ & $12-5-75$ & $\begin{array}{l}\text { Quaternary } \\
\text { alluv. } \\
\text { deposits }\end{array}$ \\
\hline $\begin{array}{l}\text { Union City, Tenn. } \\
\text { Fire Station } \\
\text { USGS, } 2450\end{array}$ & $\begin{array}{l}36.426 \\
89.061\end{array}$ & $\begin{array}{l}N \\
W\end{array}$ & $\begin{array}{l}\text { conc. b lock, } \\
\text { stl/conc. roof, } \\
\text { l-story bldg. }\end{array}$ & $\begin{array}{l}\text { ground } \\
\text { level }\end{array}$ & $10-21-77$ & $\begin{array}{l}\text { Tertiary } \\
\text { sed. rock }\end{array}$ \\
\hline $\begin{array}{l}\text { Wappape 1 10 Dam, Mo. } \\
\text { ACOE, } 2415\end{array}$ & $\begin{array}{l}36.93 \\
90.27\end{array}$ & $\begin{array}{l}N \\
W\end{array}$ & $\begin{array}{l}\text { earth dam, } \\
830 \times 34 \mathrm{~m} \mathrm{hi} \text {. } \\
\text { embankment }\end{array}$ & $\begin{array}{l}\text { crest, toe, } \\
\text { spillway }\end{array}$ & $5-25-73$ & $\begin{array}{l}\text { Ordovician } \\
\text { sed. rock }\end{array}$ \\
\hline
\end{tabular}


Table 4.- Strong-motion data from the New Madrid seismic zone

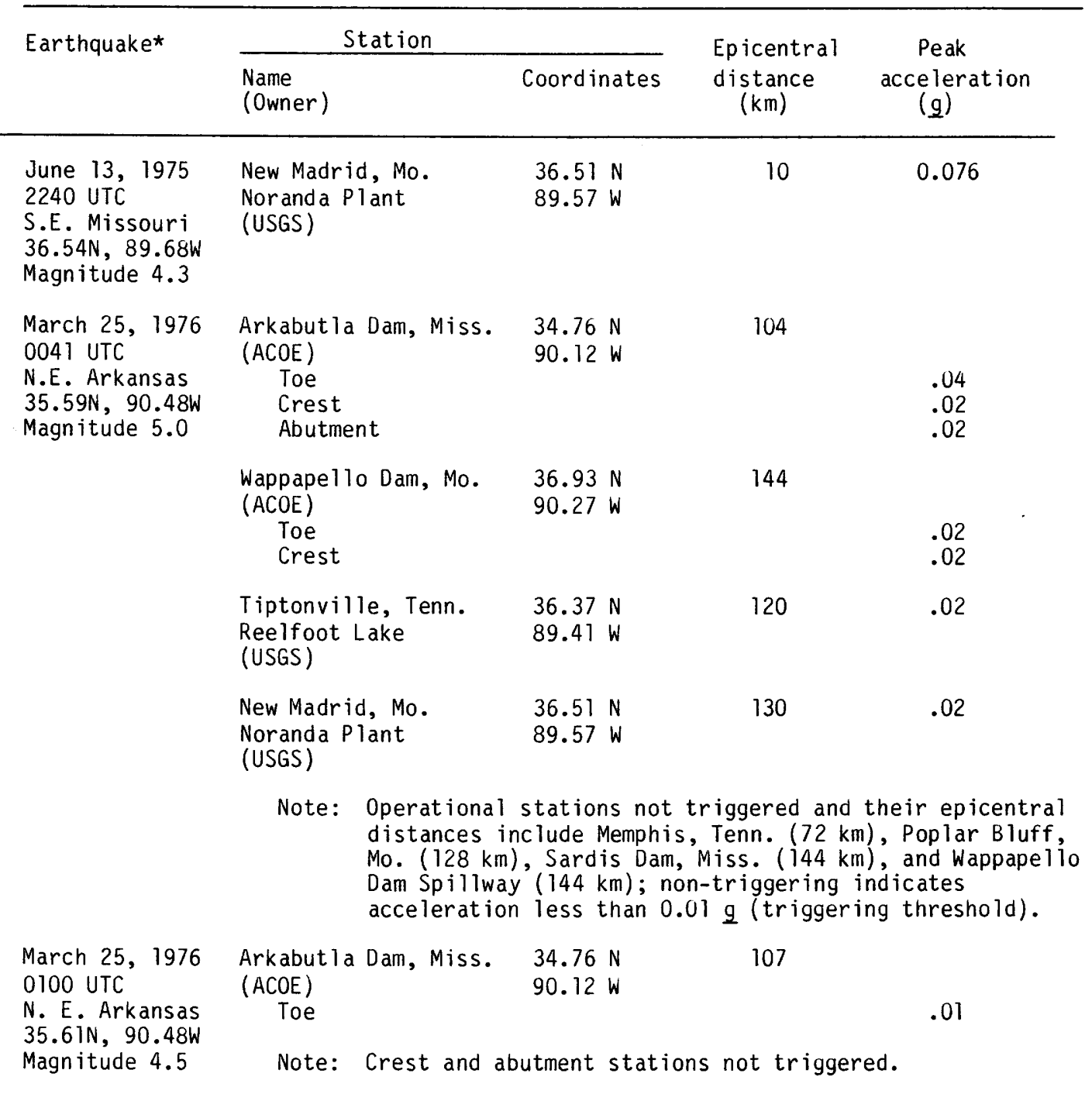

* Event information from Preliminary Determination of Epicenters, published by the U.S. Geological Survey. 
motion database presently available for the New Madrid seismic zone. These data have been processed and the raw digitized accelerograms, calculated ground accelerations, velocities, and displacements are available in Herrmann (1977).

Although the current database is inadequate, it is anticipated that a future earthquake (magnitude $51 / 2$ or greater) in the Mississippi Embayment region will trigger most of the stations in the expanded New Madrid network and provide a significant and unique strong-motion data set for use in the investigation of the spectral characteristics and attenuation of ground motion and in seismological and earthquake hazards studies of the central United States.

References:

Herrmann, R. B., 1977, Analysis of strong-motion data from the New Madrid seismic zone: 1975-1976: National Science Foundation, RANN Grant ENV 76-20875, St. Louis Univ., St. Louis, Mo. 63103, 144 p.

Matthiesen, R. B., 1978, On the development of strong-motion instrument networks in the United States: U.S. Geological Survey Open-File Report 78-1024, $91 \mathrm{p}$.

Porcella, R. L., 1978, Strong-motion instrumentation in the central and eastern United States: Earthquake Notes, v. 49, n. 2, p. 3-14.

Stauder, W., Herrmann, R., Singh, S., Perry, R., Haug, E., and Morrissey, S., 1980, Central Mississippi Valley Earthquake Bulletin, St. Louis University, St. Louis, Mo. 63103, 44 p.

willden, R., and Carlson, J. E., 1968, Transcontinental geophysical survey $\left(35^{\circ}-39^{\circ} \mathrm{N}\right)$, geologic map from $87^{\circ}$ to $100^{\circ} \mathrm{W}$ longitude: Miscellaneous Geologic Investigations Map I-534-C, scale $1: 1,000,000$.

\section{SUMMARIES OF RECENT STRONG- MOTION REPORTS $\star$}

\section{GUIDELINES FOR STRONG-MOTION \\ INSTRUMENTATION OF HIGHWAY BRIDGES}

By Christopher Rojahn and J. D. Raggett

This report suggests guidelines for the strong-motion instrumentation of highway grade separation bridges. It has been written for the civil or structural engineer who is not familiar with the objectives of strong-motion instrumentation programs, the instrumentation utilized in such programs, and where and how to install that instrumentation.

The report is divided into 10 principal sections. The first section is a general discussion on strong-motion instrumentation and records. In the second and third sections, instrumentation program objectives and criteria for selecting a bridge for strong-motion instrumentation are introduced. The fourth section is a discussion on the linear dynamic behavior of bridges that is designed to familiarize the reader with the theoretical aspects of bridge response. In the fifth section, the failure of highway bridges during the 1971 San Fernando earthquake is discussed, and in the sixth section, recommended guidelines for instrument placement on and adjacent to bridge structures are presented. The seventh and eighth sections describe recommended instrumentation types, installation techniques, and maintenance requirements, and the ninth contains a complete description of an actual strong-motion instrumentation scheme installed on a continuous two-span bridge near El Centro, California. The last (tenth) section contains concluding remarks, followed by a list of references and an appendix containing a discussion on the positive and negative aspects of recording various quantities of motion.

This document was prepared by the U.S. Geological Survey for the Offices of Research and Development of the Federal Highway Administration, U.S. Department of Transportation (FHWA Purchase Order 5-3-0195); it is available to the public through the National Technical Information Service (NTIS; see "Data Sources," this report).

*Inclusion of strong-motion information sources is intended as a service to our readers and does not imply endorsement of these reports by the U.S. Geological Survey.

\section{RECENT AWARDS IN ENGINEERING}

\author{
National Science Foundation \\ Directorate for Engineering \\ Washington D.C. 20550
}

The National Science Foundation's Directorate for Engineering supports basic and applied research that improves our knowledge of fundamental engineering principles and provides the knowledge needed to advance engineering technology. The Directorate also seeks to strengthen our Nation's academic engineering base by its support of research at academic institutions, and through such activities as research equipment grants and special award programs for new investigators.

The Directorate consists of four Divisions and the office of Interdisciplinary Research. One of these Divisions, Civil and Environmental Engineering (CEE), supports research on structures and phenomena involving the Earth's surface (such as near-surface solids, e.g., soils, rocks, and ice, foundations and dams), the design of structures, and the flow of aboveand below-ground water. Such research is fundamental to the development and building of structures and facilities, to minimize the negative impact of the natural environment on them. 
The programs of $\mathrm{CEE}$ include earthquake hazard mitigation (EHM), which supports research in many disciplines to develop an understanding of how earthquakes impact natural and manmade facilities in order to reduce casualties, damage, and social and economic disruption. This program consists of three subelements:

\section{Design Research}

Aims to develop procedures for performing dynamic analysis of proposed or existing construction under earthquake loadings, to develop an understanding of material components subjected to damaging dynamic loads, and to develop procedures for the analysis and design of nonstructural and architectural systems subject to earthquake loadings.

\section{Siting Research}

Seeks to determine from instrumental data the nature of strong ground shaking during earthquakes, to develop analytical procedures to predict the spatial and temporal distribution of strong ground motion at different sites, to understand the dynamic behavior of soil and rocks subject to strong shaking, and to understand the behavior of the ocean, particularly its margins, due to underwater earthquakes producing damaging tsunamis.

Societal Response Research

Studies and evaluates measures used to mitigate society's loss due to earthquake (and other natural hazards) impacts, including emergency preparedness, land use planning, building codes, insurance and other economic incentives, and information and education, so that communities can organize themselves to withstand disasters with minimal impact on life and property.

Recent Awards in Engineering is a new publication. It provides information on the research awards made in each fiscal year quarter by the Directorate for Engineeriny and is aimed at those researchers, educators, administrators, and users who wish to keep abreast of the research being supported in various technical areas.

To receive future issues of Recent Awards in Engineering, send name and address to National Science Foundation, Directorate of Engineering, Program Analyst for Communications, Room $1110 \mathrm{~B}, 1800 \mathrm{G}$ Street NW, Washington, D.C. 20550.

\section{UNITED STATES STRONG MOTION PROGRAMS}

By R. D. Borcherdt and R. B. Matthiesen

Safeguarding life and property from the destructive effects of earthquakes is a major national as well as worldwide problem. Because the most widespread destructive effects of earthquakes are due to strong shaking, either directly through shaking-induced structural damage, or indirectly through shaking-induced ground failures, effective programs to measure strong ground motions generated by earthquakes are vital to national as well as international efforts to reduce earthquake hazards. Strongmotion programs in the United States are supported by a number of Federal and State agencies with coordination provided by a national program operated by the U.S. Geological Survey and supported by the National Science Foundation. The cooperative national program is designed to collect, analyze, and disseminate structural-response and groundmotion data. Agencies developing centers to process strong-motion data include the U.S. Geological Survey, the California Division of Mines and Geology, the University of Southern California, and Stanford University. Automatic digitization procedures and interactive software being developed at the centers permit rapid processing and dissemination of the data to interested researchers. The extreme importance of obtaining strong-motion data at distances less than $40 \mathrm{kms}$ from large ( $M$ greater than 7) earthquakes provides an urgent need for international cooperative efforts to acquire and disseminate near-field strong-motion data.

Reference: Proceedings of the Seventh World Conference on Earthquake Engineering, September 8-13, 1980, Istanbul Turkey: v. 2, Part II, p. 9-16.

\section{INTERPRETATION OF STRONG-MOTION EARTHQUAKE} RECORDS OBTAINED IN AND (OR) NEAR BUILDINGS

\author{
By Gary C. Hart, Christopher Rojahn, \\ and J.T.P. Yao
}

The material contained in this report constitutes the proceedings of the workshop on Interpretation of Strong-Motion Earthquake Records Obtained in and (or) near Buildings. The workshop was sponsored by the National Science Foundation and was held on April 1 and 2, 1980, at the San Francisco Airport Hilton. The main purpose of the workshop was to review existing building strong-motion instrumentation programs, to document existing procedures for processing and interpreting data from those programs, and to identify ways to improve data acquisition, analysis, and interpretation techniques.

This report presents a state-of-the-art summary of the various components of existing building strong-motion earthquake instrumentation programs. Instrumentation location, data analysis, and design applications are discussed. Recommendations are proposed.

Reference: Workshop proceedings, San Francisco, Calif., April 1-2, 1980: Mechanics and Structure Department, UCLA, Los Angeles, Calif. 90024, UCLA Report No. 8015, 137 p. 
PROCESSED DATA FROM THE GILROY ARRAY AND COYOTE CREEK RECORDS, COYOTE LAKE, CALIFORNIA, EARTHQUAKE OF AUGUST 6, 1979

\author{
By A. G. Brady, P. N. Mork, V. Perez, \\ and L. D. Porter
}

This report contains plots of the results of completed processing performed on the six close-in strong-motion records obtained from the Coyote Lake earthquake of August 6, 1979. Additional copies may be obtained from the USGS Open-File Services Section or the California Division of Mines and Geology (see "Data Sources," this report). Digital data corresponding to the plots of the analysis sections 1,2 , and 3 (uncorrected data, corrected data, and response spectra, respectively) may be obtained on magnetic tape from the EDIS (see "Data Sources," this report).

Reference: U.S. Geological Survey Open-File Report 81-42, $171 \mathrm{p}$. and California Division of Mines and Geology Preliminary Report 24.

\section{GEOLOGIC DESCRIPTION OF SELECTED STRONG-MOTION ACCELEROGRAPH SITES - PART V}

By B. L. Silverstein

This report contains summaries of geologic and engineering data and information for strong-motion stations in Berkeley (4), Oakland (2), Pleasant Hill, San Francisco (5), and San Pablo. The information is taken from published and unpublished sources on file with the Seismic Engineering Branch, U.S. Geological Survey, and includes station information, a location map, core data, lithologic logs, and a narrative of local or site geology.

Reference: U.S. Geological Survey Open-File Report 80-1140, 30 p. (see "Data Sources," this report).

\section{IN-SITU MEASUREMENTS OF SEISMIC VELOCITY AT 27 LOCATIONS IN THE LOS ANGELES, CALIFORNIA, REGION}

By James F. Gibbs, Thomas E. Fumal, and Edward F. Roth

Studies conducted in the San Francisco Bay Region have shown that average shear-wave velocity can be readily tied to quantitative estimates of ground motion such as ground amplification and earthquake intensity. Furthermore, when certain physical properties of the geologic materials such as texture, haraness, and fracture spacing are observed during geologic mapping, a method can be used to predict shear-wave velocity from the descriptions of geologic units. By measuring shearwave velocities in key units together with the above data, regional maps depicting the earth- quake shaking hazard can be compiled.

The goals of the current program are to provide shear-wave data in the Los Angeles area to compare with that in the San Francisco Bay region where high-strain intensity data are available. Data from 27 locations are summarized in this report as part of a continuing project to seismically zone the Los Angeles area.

Reference: U.S. Geological Survey Open-File Report 80-378, 167 p. (see "Data Sources," this report).

\section{STRONG-MOTION INFORMATION, DATA REPORTS, AND AVAILABILITY OF DIGITIZED DATA}

\section{U.S STRONG-MOTION NETWORK DATA}

A strong-motion information retrueval system (SMIRS) has been developed at the USGS to provide up-to-date information about strong-motion records and the circumstances in which they were recorded. The system is accessible through a data terminal ( $30 \mathrm{cps}$, half duplex). The system is operational, but the information within it is incomplete and needs to be verified. A user's manual is available (Converse, 1978). To retrieve information, dial (415) $329-8600$ and place the telephone handset into the terminal. When the carrier light comes on, press the "line-feed" key and wait for the computer to responu ( $t$ wo lines will be printed); type the following:

enter yourname SMIRS

Type the "enter" and "SMIRS" exactly as shown above, but replace "yourname" with your own name. The word "enter" is five lowercase characters followed by one space; your name is typed as one continuous character string and followed by one space; and "SMIRS" is five uppercase characters. Type the carriage-return key and then the line-feed key; you wlll be given instructions.

The strong-motion records from the February 9, 1971, San Fernando, California, earthquake and most of the significant records pricr to that event have been digitized by the California Institute of Technology (CIT) (Hucson, 1976). Processing and analysis of the data have been presented in a series of reports containing (1) uncorrected digital data, (2) corrected accelerations, velocities, and displacements, (3) response spectra, and (4) rourier amplitude spectra. All of these data reports are available through the National Technical Information Service (NTIS, see "Data Suurces," this report). The digitized data from the CIT digitization program are available from the Environmental Data and Information Service (EDIS) and the National Information Service for Earthquake Engineering at the University of California, Berkeley (NISEE, see "Data Sources," this report). The magnetic tape digital data from subsequent years will be available from EDIS and NISEE at approximately the same time as the data reports are published. 
References:

Converse, April, 1978, Strong-motion information retrieval system user's manual: U.S. Geological Survey Open-File Report, 79-289, $51 \mathrm{p}$.

Hudson, D. E., 1976, Strong-motion earthquake accelerograms - index volume: California Institute of Technology, EERI report 76-02, $72 \mathrm{p}$.

\section{CALIFORNIA DIVISION OF MINES AND GEOLOGY STRONG-MOTION DATA}

Processed strong-motion data from selected earthquakes are available from the California Division of Mines and Geology. The data have been prepared by the interim CDMG strong-motion data processing system. This system is composed of a series of programs that have been developed by the California Institute of Technology, the U.S. Geological Survey, and the California Division of Mines and Geology, with special emphasis on the handling of longduration film records from multiple-channel central recording instruments.

The data are grouped by phase:

Phase I Uncorrected accelerations,

Phase II Corrected accelerations, velocities, and displacements,

Phase III Response spectra.

Each phase contains three-channel subgroups arranged by station. At the present time, data from the following earthquakes have been processed:

Santa Barbara earthquake of August 13, 1978

\section{Station}

UCSB Goleta

UCSB North Hall

Freitas Building

\section{Channels}

9
- Imperial Valley earthquake of October 15, 1979

$\begin{array}{lr}\text { El Centro free-field } & 3 \\ \text { Imperial County Services Bldg. } & 13\end{array}$

The data are available on standard nine-track tapes, along with a microfiche copy of the tape contents. Interested parties should contact the CDMG Office of Strong-Motion Studies (see "Data Sources," this report).

It is the policy of the CDMG to make all strong-motion record data promptly available to the public in a manner consistent with good data management. Requests for copies of records, personal access to record or data files, and copies of data files should be made to the Chief, Office of Strong-Motion Studies (OSMS), and should specify identity and medium of materials to be provided or reviewed. Desired access or delivery dates should be specific. When a request for copies of materials or personal access to files is received, OSMS staff will provide the requested material or will set an appointment time for personal review of files; the requestor will be notified immediately of any significant delay or other problems that prevent meeting the request. Charges for copying or other processing of materials will be based on the actual cost of producing and delivering the items, and OSMS will retain control of originals and master copies of all items.

\section{FOREIGN STRONG-MOTION DATA}

Because of the long history of close cooperation between the United States and the Central and South American strong-motion programs, much of the data from those programs are available from the same sources as the United States data (see below). Information about strong-motion data from the Western Hemisphere will be included in the Strong-Motion Information Retrieval System operated by the USGS.

The USGS does not attempt to obtain firstclass copies of records from those foreign organizations that prepare data reports comparable to those prepared by the USGS. Abstracts of the data reports from such organizations are presented in this Seismic Engineering Program Report series, and through informal arrangements, copies of the data and records are made available.

\section{EDIS/NOAA WORLDWIDE STRONG-MOTION DATA}

A worldwide collection of strong-motion seismograms for dissemination to the scientific and engineering community is available from World Data Center A for Solid Earth Geophysics and the National Geophysical and SolarTerrestrial Data Center (NGSDC). Countries contributing to the strong-motion data base include Australia, Italy, Japan, New Zealand, Rumania, U.S.S.R., and Yugoslavia. The U.S. Geological Survey has furnished records from its network of cooperative strong-motion stations, including those in Central and South America.

Copies of strong-motion records are available on $35-\mathrm{mm}$ film, on $70-\mathrm{mm}$ film chips, as paper copies, and as digitized data on punched cards or magnetic tape. A list of most records can be obtained from the World Data Center A publication "Catalog of Seismograms and StrongMotion Records," Report SE-6. This catalog can be ordered from NGSDC (EDIS/NOAA) for $\$ 3.00$ (see "Data Sources," this report).

The most significant strong-motion records recorded in the United States and Latin America between 1931 and 1971 have been copied on seven reels of $35-\mathrm{mm}$ film ( $x 12$ reduction) and $70-\mathrm{mm}$ film chips (approximately $\times 8$ reduction). The 
film chips are available for $\$ 1.50$ per chip; longer records are continued on additional chips. The 35-mm film copies can be purchased for $\$ 30$ per reel, the complete set of reels for $\$ 180$. There is a minimum charge of $\$ 10$ per order.

Japan and Australia have supplied magnetic tapes of digitized data from stations locateo in the western Pacific Ocean (the Japanese Islands, New Guinea, and New Britain). A series of 400 United States strong-motion records (1933-1971) were digitized by the California Institute of Technology and are now available on six magnetic tapes. The U.S. Geological Survey is digitizing post-1971 records from its network; they have generated 15 tapes of strong-motion records recorded from 1967 to 1975 in the United States, Chile, Nicaragua, San Salvador, and Mexico.

Other digitized data include punched cards containing strong-motion records from the March 4, 1977, earthquake in Rumania (recorded in Bucharest); the Gazli earthquake of May 17, 1976, in Uzbek, U.S.S.R.; and three earthquakes in the New Madrid seismic zone (located in midcontinental United States) in 1975 and 1976.

Recent acquisitions include a magnetic tape of strong-motion records triggered by a swarm of earthquakes that occurred in northern Italy near the town of Friuli in 1976; these were compiled by the National Commission for Nuclear Energy and have been given to the center for distribution. Other data include records obtained from California earthquakes near Santa Barbara in August. 1978, Gilroy in August 1979, El Centro in October 1979, and Livermore in January 1980.

A table listing all digitized strong-motion records available on magnetic tape may be obtained free of charge from EDIS/NOAA. Digitized strong-motion records may be purchased either in punched card format at $\$ 60$ per record (including all three instrument components) or in tape format at $\$ 80$ per tape.

Checks or money orders should be made payable to "Commerce/NOAA/NGSDC"; inquiries should be addressed to EDIS/NOAA (see "Data Sources," this report).

\section{DATA SOURCES}

For reports or information regarding strong-motion records and data, address inquiries to the appropriate agency listed below:

1. Branch of Distribution

(804) 756-6141

U.S. Geological Survey

604 So. Pickett Street

(FTS) 756-6141

Alexandria, VA 22304

2. Earthquake Engineering

(415) 848-0972

Research Institute

2620 Telegraph Avenue

Berkeley, CA 94704

3. EDIS/NOAA

National Geophysical and Solar-Terrestrial Data

Center (D622)

Boulder, CO 80303

4. National Technical Information Service

(703) $487-4650$

(FTS) $737-4650$

5285 Port Royal Road

U.S. Dept. of Commerce

Springfield, VA 22161

5. NISEE/Computer Applications (415) 642-5113 519 Davis Hall, UC Berkeley

Berkeley, CA 94720.

6. Office of Strong-Motion

(916) $322-3105$

Studies

California Division of Mines and Geology

2811 "O" Street

Sacramento, CA 95816

7. Open-File Services Section (303) 234-5888 Branch of Distribution

U.S. Geological Survey

Box 25425, Federal Center

Denver, CD 80225

8. Seismic Engineering Branch (415) 323-8111 U.S. Geological Survey

345 Middlefield Road, MS 78 (FTS) 467-2881 Menlo Park, CA 94025. ext 2881

(FTS) 234-5888 


\section{ERRATA}

\section{Reference}

CIT; EERL S-M earthquake accelerograms, digitized \& plotted data; vol II, III, IV; Part B; Record \#037

(1966 Parkfield earthquake)

same as above:

vol I, II; Part C

Record \#041 (1971 San

Fernando earthquake;

Component direction-

Pacoima Dam accelerogram)

USGS S-M Station No. 1250

Gilroy, Gavilan College

(Component direction - al1

S-M records from Oct. 1972

to Aug. 1979)

USGS S-M Station 2420

New Madrid, Missouri

Component directionevents of 6-13-75 and $3-24-76$ )

USGS S-M Station no. 181; Los Angeles, 640 Marengo,

lst floor (Comporient

direction prior to 7-15-70)

NOTE: Since 7-15-70, the 1st floor (a)so 4th

floor and roof) component directions are:

USGS S-M Station No. 122;

Glendale, California

Component direction -

events of $4 / 8 / 68$ and

2/9/71)

USGS S-M Station No. 125(828);

Lake Hughes Array Station 1

TTA) Component direction:

event $9 / 12 / 70$

$L-S 70 E$

$V-$ Down

T - S2OW
Correction

Temblor, Calif.

USGS Station No. 1438

$3542^{\prime} 36^{\prime \prime} \mathrm{N}$

$12010^{\prime} 12^{\prime \prime} \mathrm{W}$

L - N76W

$V$ - Down

$T-S 14 W$

$L-S 67 W$

V - Down

T - S23E

L - West

$v$ - Down

T - South
$L-S 54 W$

V - Down

T - S36E

$L-N 36 W$

$V$ - Down

$T$ - S54W

L - S72E

$V$ - Down

$T$ - N18E

event $2 / 9 / 71$

L - N2 IE

$V$ - Down

T - N69W

$L-N 21 E$

$V$ - Down

T - S69E
$L-S 21 W$

$V$ - Down

$T$ - S69E

$L-S 21 W$

$V$ - Down

$T$ - S69E 
Table 1. - Summary of accelerograms recovered during May - August 1980

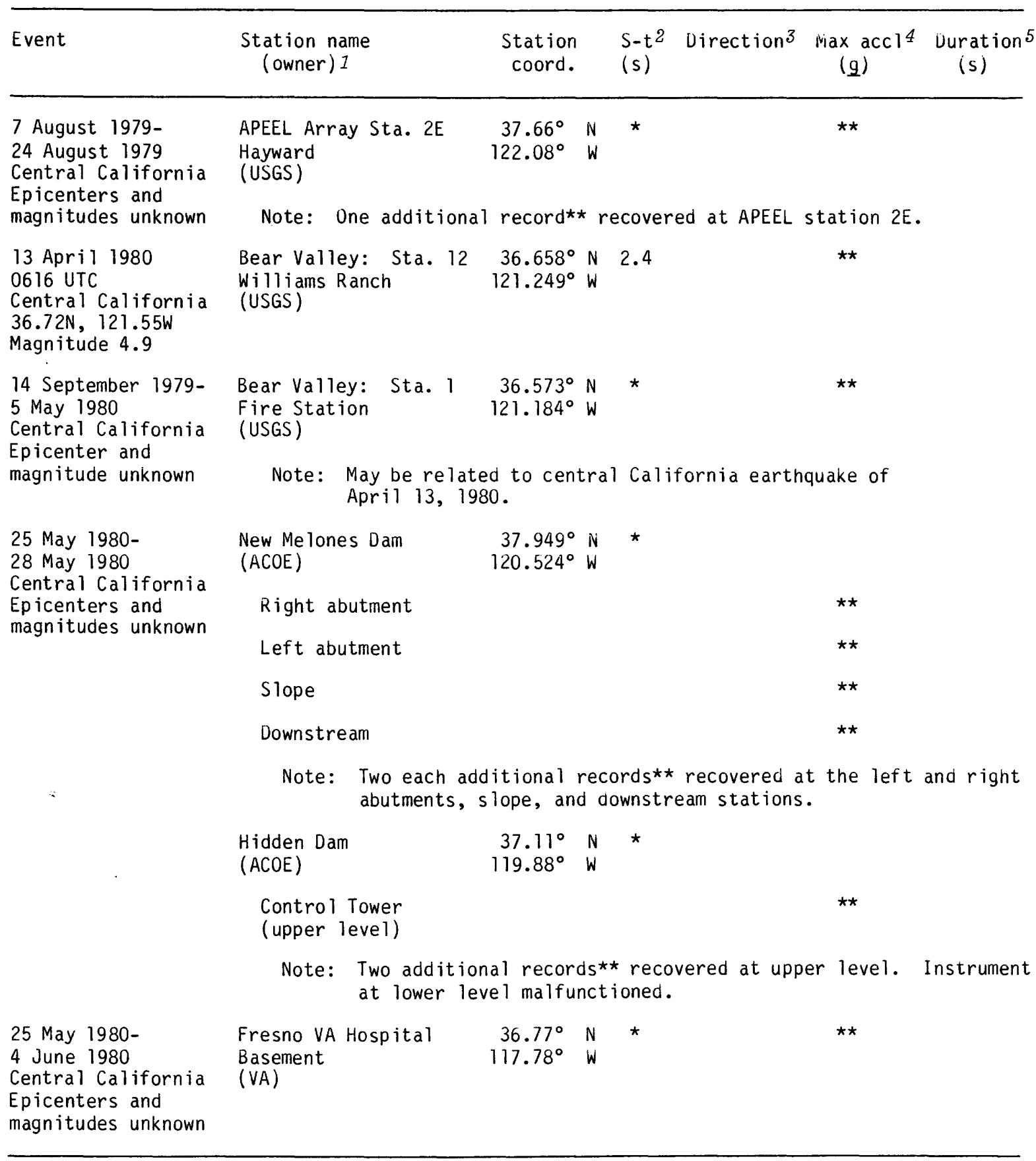

See footnotes at end of table. 
Table 1. - Summary of accelerograms recovered during May - August 1980 - continued

\begin{tabular}{|c|c|c|c|c|c|c|}
\hline Event & $\begin{array}{l}\text { Station name } \\
\text { (owner) })^{I}\end{array}$ & $\begin{array}{l}\text { Station } \\
\text { coord. }\end{array}$ & $\begin{array}{l}S-t^{2} \\
(s)\end{array}$ & Direction 3 & $\begin{array}{l}\operatorname{Max} \operatorname{accl}^{4} \\
(\mathrm{~g})\end{array}$ & $\underset{(s)}{\text { Duration }}$ \\
\hline \multirow[t]{4}{*}{$\begin{array}{l}25 \text { May } 1980- \\
4 \text { June } 1980 \\
\text { - cont inued- }\end{array}$} & $\begin{array}{l}\text { Dos Amigos } \\
\text { Pumping plant } \\
\text { (CDWR) }\end{array}$ & $\begin{array}{r}36.92^{\circ} \\
117.78^{\circ}\end{array}$ & * & & & \\
\hline & Level 1 & & & & $\star \star$ & \\
\hline & Level 4 & & & & $\star \star$ & \\
\hline & Note: One ea & Iditional $\mathrm{re}$ & ords** & recovered at & $t$ levels 1 & and 4 . \\
\hline \multirow{17}{*}{$\begin{array}{l}25 \text { May } 1980- \\
5 \text { June } 1980 \\
\text { Central California } \\
\text { Epicenters and } \\
\text { magnitudes unknown }\end{array}$} & $\begin{array}{l}\text { Isabel la Dam } \\
\text { (ACOE) }\end{array}$ & $\begin{array}{r}35.65^{\circ} \\
118.48^{\circ}\end{array}$ & * & & & \\
\hline & Crest & & & & $\star \star$ & \\
\hline & Toe & & & & $\star \star$ & \\
\hline & $\begin{array}{l}\text { Lower spillway } \\
\text { gallery }\end{array}$ & & & & $\star \star$ & \\
\hline & $\begin{array}{c}\text { Note: Two ea } \\
\text { lower }\end{array}$ & $\begin{array}{l}\text { ditional re } \\
\text { way gallery }\end{array}$ & $\operatorname{ords} s^{\star \star}$ & recovered at & crest, to & e, and \\
\hline & $\begin{array}{l}\text { Isabell a Aux. Dam } \\
\text { (ACOE) }\end{array}$ & $\begin{aligned} 35.64^{\circ} & N \\
118.47^{\circ} & W\end{aligned}$ & * & & & \\
\hline & Crest & & & & $\star \star$ & \\
\hline & Tower & & & & $\star \star$ & \\
\hline & \multicolumn{3}{|c|}{ Note: Two each additional records** } & recovered at & crest and & tower. \\
\hline & $\begin{array}{l}\text { Lake Success Dam } \\
(A C O E)\end{array}$ & $\begin{array}{r}36.061^{\circ} \mathrm{N} \\
118.920^{\circ} \mathrm{W}\end{array}$ & 16.5 & & & \\
\hline & Downstream & & & $\bigcup_{195^{\circ}}^{285^{\circ}}$ & $\begin{array}{l}0.05 \\
.02 \\
.06\end{array}$ & $\begin{array}{l}- \\
-\end{array}$ \\
\hline & Right abutment & & & & $\star \star$ & \\
\hline & Left crest & & & & $\star \star$ & \\
\hline & Left abutment & & & & $\star \star$ & \\
\hline & Right crest & & & & $\star \star$ & \\
\hline & Slope & & & & $\star \star$ & \\
\hline & 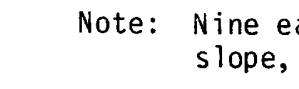 & $\begin{array}{l}\text { ditional } r \\
\text { and right }\end{array}$ & $\begin{array}{l}\text { ords } \star \star \\
\text { utment }\end{array}$ & $\begin{array}{l}\text { recovered at } \\
s \text {, and left }\end{array}$ & $\begin{array}{l}\text { it downstre } \\
\text { and right }\end{array}$ & $\begin{array}{l}\text { am, } \\
\text { crests. }\end{array}$ \\
\hline
\end{tabular}

See footnotes at end of table. 
Table 1. - Sumary of accelerograms recovered during May - August 1980 - continued

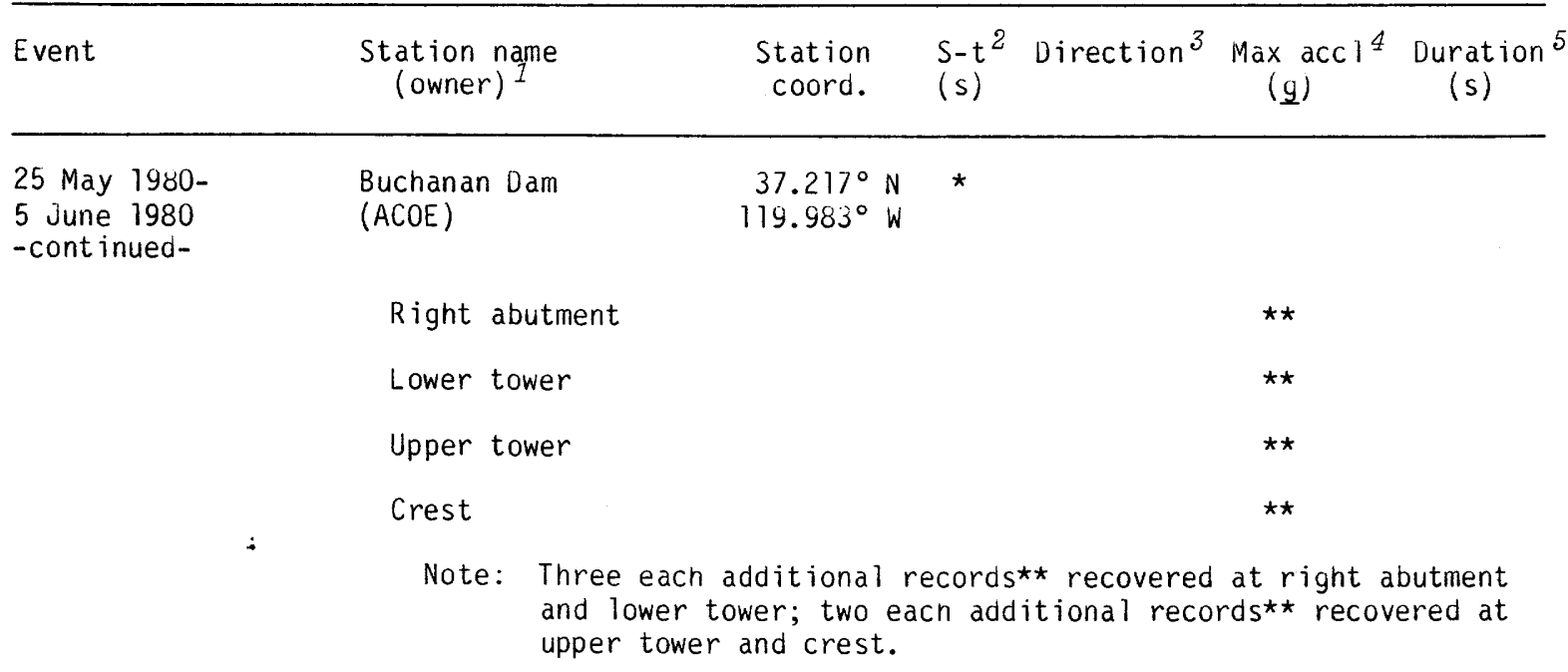

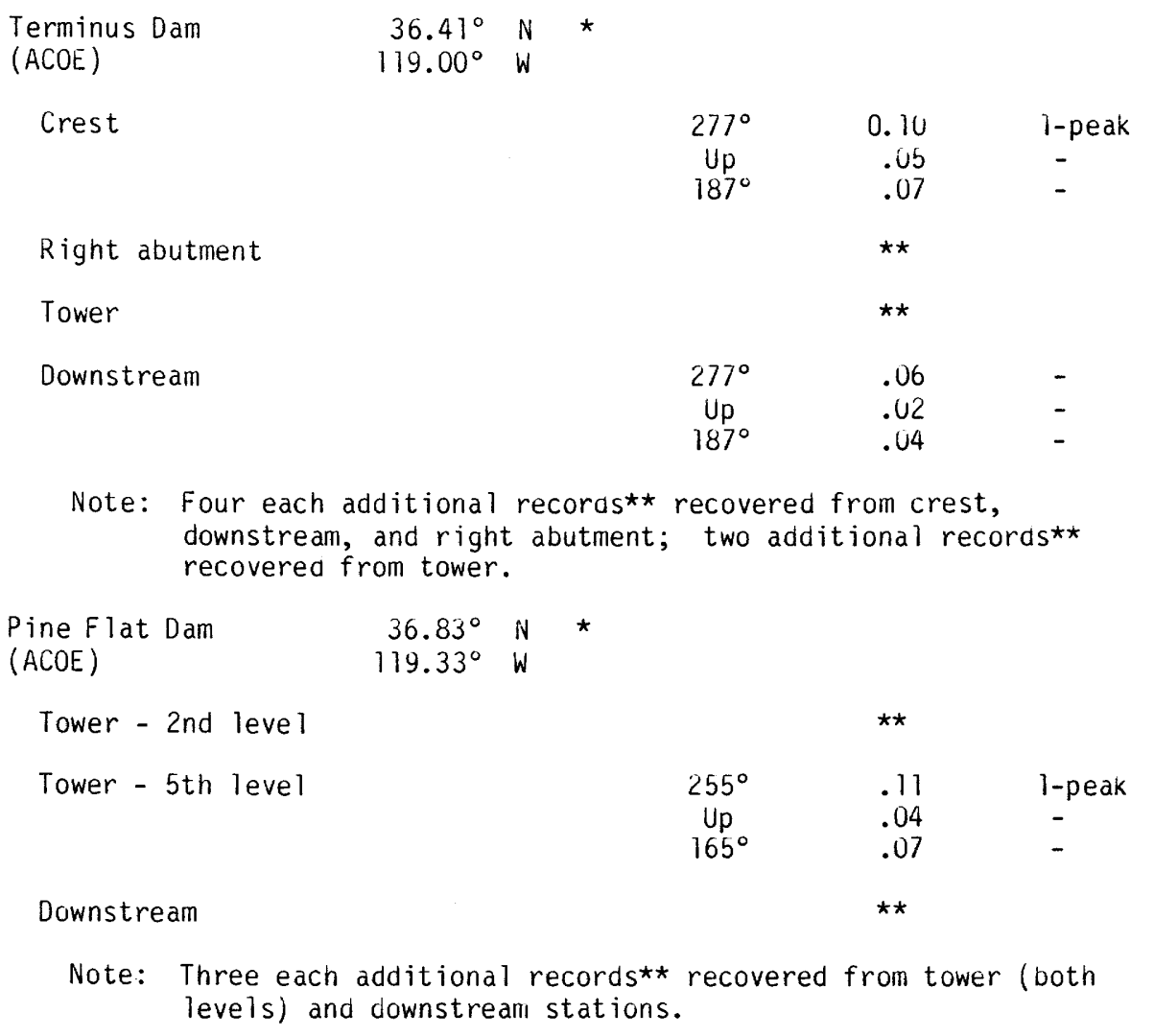

See footnotes at end of table. 
Table 1. - Summary of accelerograms recovered during May - August 1980 - continued

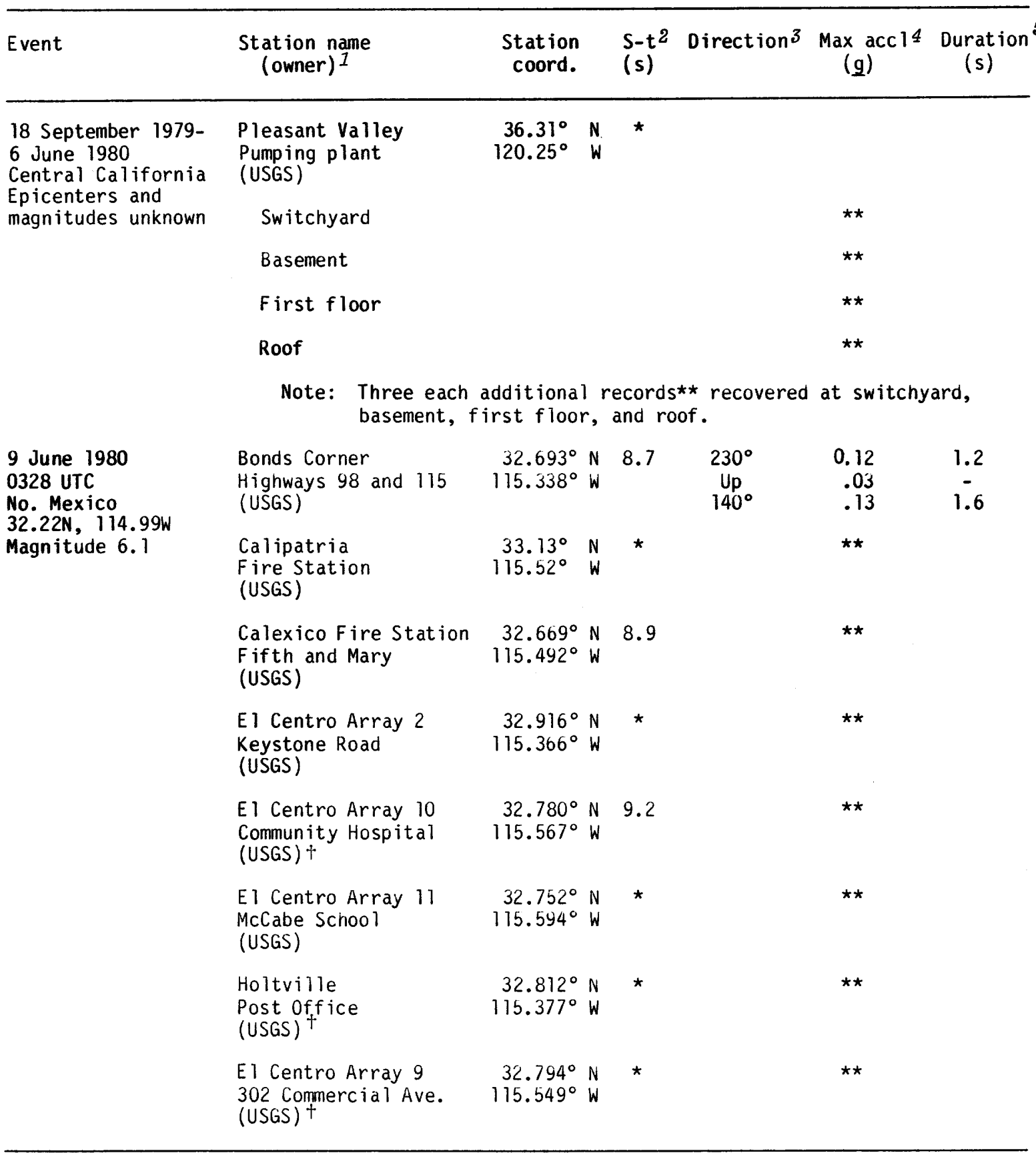

See footnotes at end of table. 
Table 1. - Summary of accelerograms recovered during May - August - continued

\begin{tabular}{|c|c|c|c|c|c|c|c|}
\hline Event & $\begin{array}{l}\text { Station name } \\
\text { (owner) }{ }^{1}\end{array}$ & $\begin{array}{l}\text { Station } \\
\text { coord. }\end{array}$ & & $\begin{array}{l}s-t^{2} \\
(s)\end{array}$ & Direction 3 & $\begin{array}{l}\operatorname{Max} \operatorname{accl}^{4} \\
(\mathrm{~g})\end{array}$ & $\begin{array}{l}\text { Duration } \\
\quad(\mathrm{s})\end{array}$ \\
\hline $\begin{array}{l}9 \text { June } 1980 \\
\text { 0328 UTC } \\
\text { - cont inued- }\end{array}$ & $\begin{array}{l}\text { Yuma, Arizona } \\
\text { Strand Avenue } \\
\text { (USBR/USGS) }\end{array}$ & $\begin{array}{r}32.73^{\circ} \\
114.70^{\circ}\end{array}$ & $\begin{array}{l}N \\
W\end{array}$ & * & & ** & \\
\hline $\begin{array}{l}7 \text { March } 1980- \\
23 \text { June } 1980 \\
\text { Central Cal ifornia } \\
\text { Epicenter and }\end{array}$ & \multicolumn{2}{|l|}{$\begin{array}{l}\text { Bear Valley: Sta. } \\
\text { Schroll Ranch } \\
\text { (USGS) }\end{array}$} & $\begin{array}{l}N \\
W\end{array}$ & * & & ** & \\
\hline magnitude unknown & \multicolumn{3}{|c|}{$\begin{array}{l}\text { May be related to central } \\
\text { April } 13,1980 .\end{array}$} & \multicolumn{3}{|c|}{ California earthquake of } & \\
\hline $\begin{array}{l}19 \text { August } 1979- \\
24 \text { June } 1980 \\
\text { Central California } \\
\text { Epicenter and }\end{array}$ & $\begin{array}{l}\text { Gilroy Array Sta. } 2 \\
\text { Mission Trails Motel } \\
\text { (CDMG) }\end{array}$ & $\begin{array}{r}36.982^{\circ} \\
121.556^{\circ}\end{array}$ & $\begin{array}{l}N \\
W\end{array}$ & * & $\begin{array}{l}140^{\circ} \\
\text { Up } \\
050^{\circ}\end{array}$ & $\begin{array}{r}0.08 \\
.03 \\
.07\end{array}$ & $\begin{array}{l}- \\
-\end{array}$ \\
\hline magnitude unknown & $\begin{array}{l}\text { Gilroy Array Sta. } 3 \\
\text { Sewage Plant } \\
\text { (CDMG) }\end{array}$ & $\begin{array}{r}36.991^{\circ} \\
121.536^{\circ}\end{array}$ & $\begin{array}{l}N \\
W\end{array}$ & * & $\begin{array}{l}140^{\circ} \\
U p \\
050^{\circ}\end{array}$ & $\begin{array}{l}.03 \\
.02 \\
.06\end{array}$ & $\begin{array}{l}- \\
-\end{array}$ \\
\hline
\end{tabular}

Note: May be related to central California earthquake of April 13, 1980.

27 July 1980

1852 UTC

Maysville, Kentucky

$38.17 \mathrm{~N}, 83.91 \mathrm{~W}$

Magnitude 5.2

24 August 1980

1241 UTC

Central California

$37.57 \mathrm{~N}, 121.67 \mathrm{~W}$

Magnitude 4.1
Laure 1 River Dam

Crest

$(A C O E)+$

Nol in River Dam

Center crest

$(A C O E)+$

Livermore

VA Hospital, Bldg. 62

(VA $)^{+}$

\section{Basement}

Roof (7)

Del valle Dam

$(\text { COWR })^{+}$

crest

Toe $36.967^{\circ} \mathrm{N}$ *

$84.268^{\circ} \mathrm{W}$

$37.277^{\circ} \mathrm{N}$ *

$86.247^{\circ} \mathrm{W}$

$37.625^{\circ} \mathrm{N}$ *

$121.762^{\circ} \mathrm{W}$ 
Table 1. - Summary of accelerograms recovered during May - August 1980 - continued

\begin{tabular}{|c|c|c|c|c|c|c|}
\hline Event & $\begin{array}{l}\text { Station name } \\
\text { (owner) } 1\end{array}$ & $\begin{array}{c}\text { Station } \\
\text { coord. }\end{array}$ & $\begin{array}{l}\mathrm{S}-\mathrm{t}^{2} \\
(\mathrm{~s})\end{array}$ & Direction 3 & $\begin{array}{l}\operatorname{Max} \operatorname{accc}^{4} \\
(\mathrm{~g})\end{array}$ & $\begin{array}{l}\text { Duratione } \\
(\mathrm{s})\end{array}$ \\
\hline
\end{tabular}

$\begin{array}{llrl}23 \text { August 1979- } & \text { San Francisco } & 37.79^{\circ} & \mathrm{N} \\ 9 \text { April 1987 } & \text { Bank of America Bidg. } 122.40^{\circ} & \mathrm{W} \\ \text { Central California } & \text { (USGS) } & & \end{array}$

Epicenters and

magnitudes unknown

Basement (3rd)
Concourse
22nd floor
52nd floor

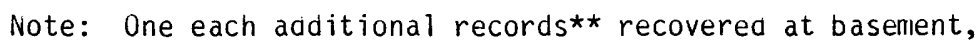
concourse, 22nd, and 52nd floor. May be related to Livermore earthquakes of January 24 and 26, 1980.

\footnotetext{
${ }^{1}$ Station owner code:

ACOE - U.S. Army Corps of Engineers.

CDMG - California Division of Mines and Geology.

COWR - California Department of Water Resources.

USBR - U.S. Bureau of Reclamation.

USGS - U.S. Geological Survey.

VA - Veterans Administration.

+ - WWVB time code not legible or instrument not equipped with a radio receiver; correlation of accelerogram with event may be questionable.

${ }^{2} S$-wave arrival minus trigger time $(S-t)$ interval.

* $\mathrm{S}-\mathrm{t}$ time is questionable or cannot be determined.

3 Direction of case acceleration for upward trace deflection on accelerogram. Horizontal components are listed as azimuth in degrees clockwise from north. Vertical components are listed as "up" or "down."

4 Peak acceleration recorded at ground level on one vertical and two horizontal orthogonal components unless otherwise noted.

$\star \star$ Denotes maximum acceleration is less than $0.05 \mathrm{~g}$ at ground level or less than $0.10 \mathrm{~g}$ at non ground-level stations.

5 Duration between first and last peaks of acceleration greater than $0.10 \mathrm{~g}$.
} 



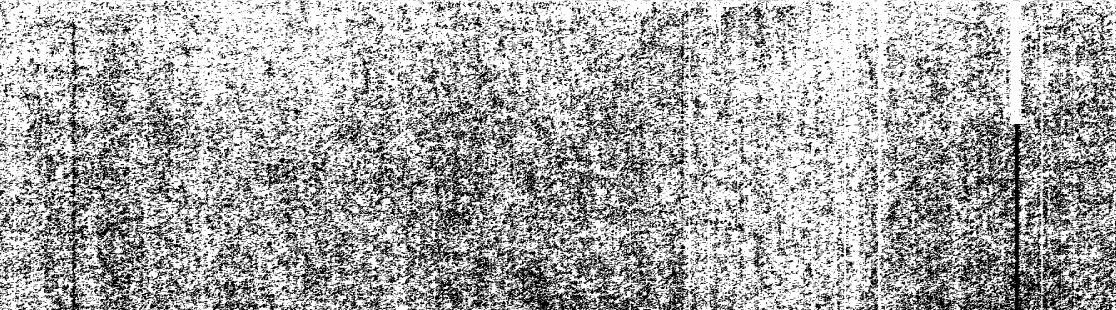

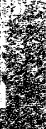

the

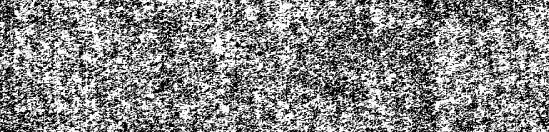

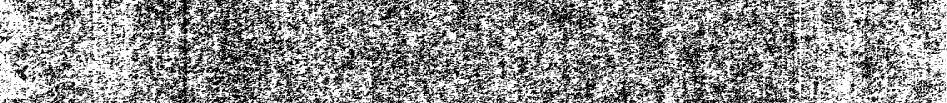

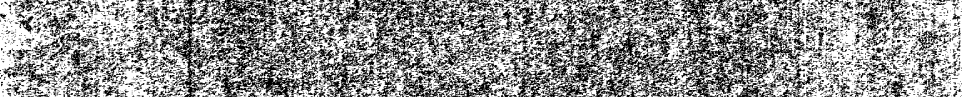

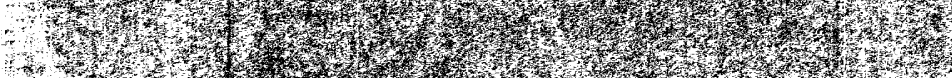

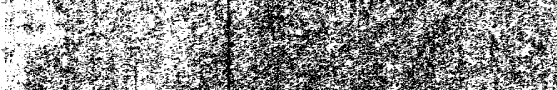

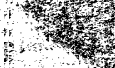

Whenthe

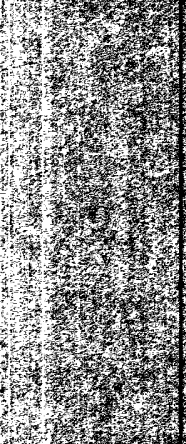

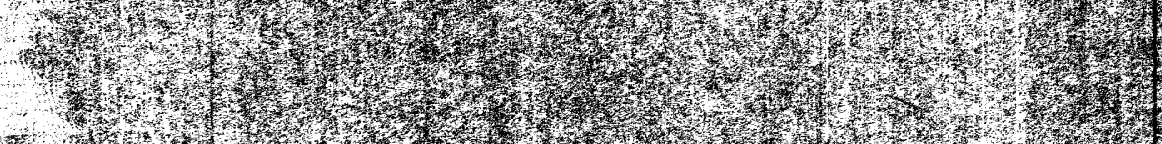
H.

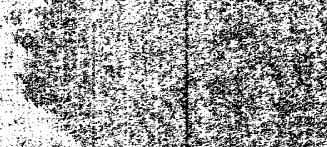

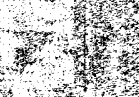

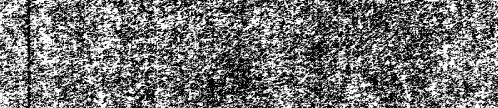

Mr

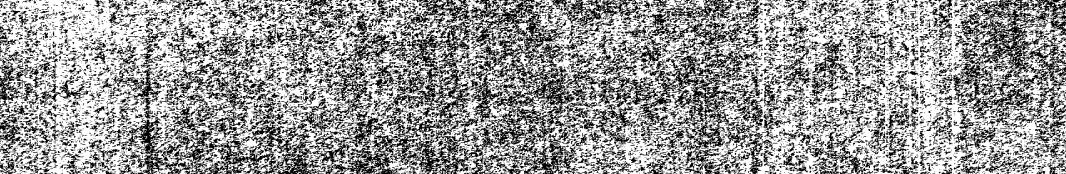

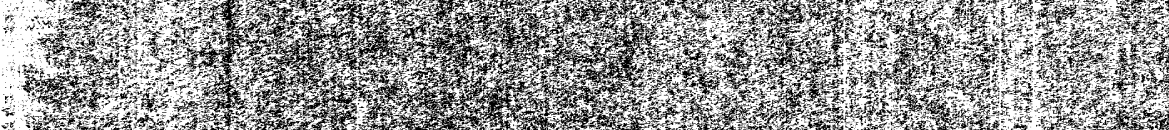

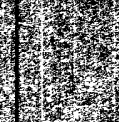

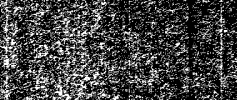
(1)

Mr

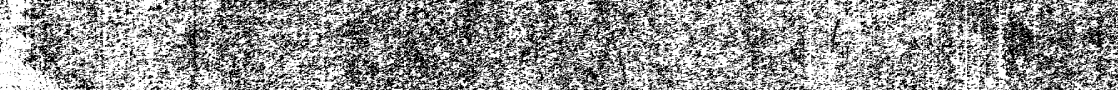

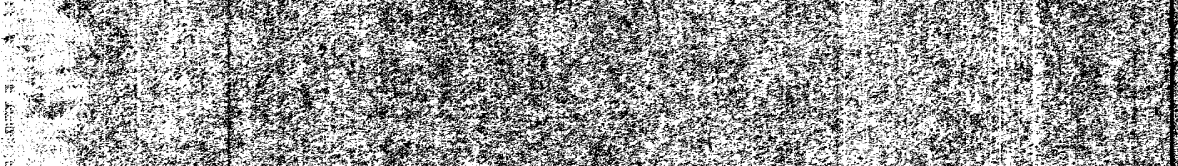

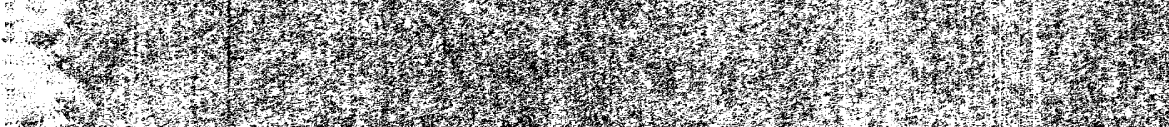



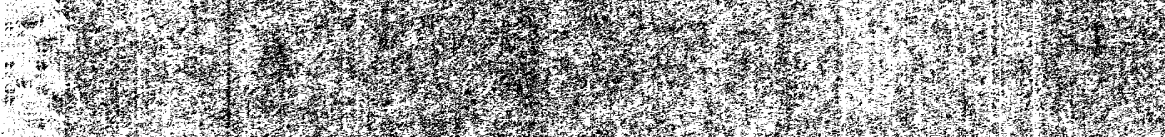

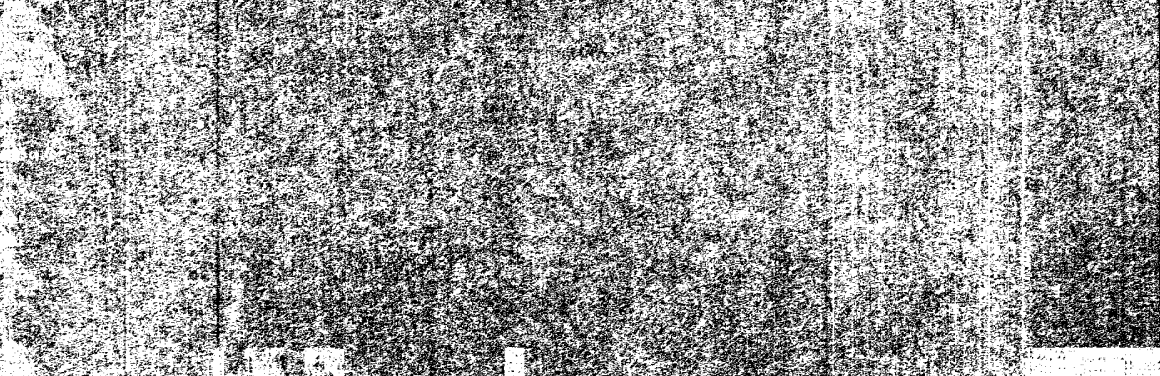


